\title{
4. SEDIMENTOLOGY OF DEEP-WATER VOLCANICLASTICS, OLIGOCENE IZU-BONIN FOREARC BASIN, BASED ON FORMATION MICROSCANNER IMAGES ${ }^{1}$
}

\author{
R. N. Hiscott, ${ }^{2}$ A. Colella, ${ }^{3}$ P. Pezard,${ }^{4}$ M. A. Lovell,${ }^{5}$ and A. Malinverno ${ }^{6}$
}

\begin{abstract}
Three sites were drilled in the Izu-Bonin forearc basin during Ocean Drilling Program (ODP) Leg 126. High-quality formation microscanner (FMS) data from two of the sites provide images of part of a thick, volcaniclastic, middle to upper Oligocene, basin-plain turbidite succession. The FMS images were used to construct bed-by-bed sedimentary sections for the depth intervals 2232-2441 m below rig floor (mbrf) in Hole 792E, and 4023-4330 mbrf in Hole 793B. Beds vary in thickness from those that are near or below the resolution of the FMS tool $(2.5 \mathrm{~cm})$ to those that are $10-15 \mathrm{~m}$ thick. The bed thicknesses are distributed according to a power law with an exponent of about 1.0. There are no obvious upward thickening or thinning sequences in the bed-by-bed sections. Spaced packets of thick and very thick beds may be a response to (1) low stands of global sea level, particularly at $30 \mathrm{Ma}$, (2) periods of increased tectonic uplift, or (3) periods of more intense volcanism.

Graded sandstones, most pebbly sandstones, and graded to graded-stratified conglomerates were deposited by turbidity currents. The very thick, mainly structureless beds of sandstone, pebbly sandstone, and pebble conglomerate are interpreted as sandy debris-flow deposits. Many of the sediment gravity flows may have been triggered by earthquakes. Long recurrence intervals of $0.3-1 \mathrm{~m} . \mathrm{y}$. for the very thickest beds are consistent with triggering by large-magnitude earthquakes $(M=9)$ with epicenters approximately 10-50 km away from large, unstable accumulations of volcaniclastic sand and ash on the flanks of arc volcanoes.

Paleocurrents were obtained from the grain fabric of six thicker sandstone beds, and ripple migration directions in about 40 thinner beds; orientations were constrained by the FMS images. The data from ripples are very scattered and cannot be used to specify source positions. They do, however, indicate that the paleoenvironment was a basin plain where weaker currents were free to follow a broad range of flow paths. The data from sandstone fabric are more reliable and indicate that turbidity currents flowed toward $150^{\circ}$ during the time period from 28.9 to $27.3 \mathrm{Ma}$. This direction is essentially along the axis of the forearc basin, from north to south, with a small component of flow away from the western margin of the basin.
\end{abstract}

\section{INTRODUCTION}

Sites 787,792 , and 793 were drilled in the forearc basin of the Izu-Bonin Arc (Fig. 1). The thickest stratigraphic unit at all three sites is a lower to upper Oligocene turbidite succession derived from the contemporary Izu-Bonin intraoceanic arc (Fujioka and Saito, this volume; Hiscott and Gill, this volume). The Oligocene basin, formed by extension (Leg 126 Shipboard Drilling Party, 1989; Taylor et al., 1990; Taylor, this volume), was elongate parallel to the volcanic arc and had a width of about $60 \mathrm{~km}$. The eastern margin of the basin consisted of Eocene arc volcanic rocks, including boninites, that form the basement of the outer-arc high at Leg 125 Sites 782 and 786 (Fryer, Pearce, et al., 1990). Rocks that were to the west of this basin in the Oligocene were split into two parts by the Miocene opening of the Shikoku Basin: one part is beneath the modern volcanic front; the other is beneath the Palau-Kyushu Ridge (Kobayashi and Nakada, 1979). These volcanic rocks are also Eocene, as proved by a radiometric date of $48.5 \pm 1.4 \mathrm{Ma}$ for volcanic rocks of the Palau-Kyushu Ridge (Matsuda, 1985). Also, Yuasa (1985) argues that the basement beneath the modern volcanic front can be traced southward, across the Sofugan tectonic line (Fig. 1B), into the area of the Bonin Islands,

\footnotetext{
'Taylor, B., Fujioka, K., et al., 1992. Proc. ODP, Sci. Results, 126: College Station, TX (Ocean Drilling Program)

${ }^{2}$ Sciences Department and Centre for Earth Resources Research, Memorial University of Newfoundland, St. John's, Newfoundland, A1B 3X5, Canada.

${ }^{3}$ Dipartimento di Scienze della Terra, Università della Calabria, 87030 Arcavacata (Cosenza), Italy.

${ }^{4}$ Institut Méditerranéen de Technologie, Technopôle de Château-Gombert, 13451 Marseille Cedex 13, France.

${ }^{5}$ Geology Department, Leicester University, University Road, Leicester, LE1 7RH, United Kingdom.

${ }^{6}$ Marine Geology and Geophysics, Lamont-Doherty Geological Observatory, Columbia University, Palisades, NY 10964, U.S.A.
}

where Eocene volcanics, including boninites, crop out (Kuroda and Shiraki, 1975; Tsunakawa, 1983; Matsuda, 1985).

Paleomagnetic results from Leg 126 (Koyama et al., this volume) confirm a $90^{\circ}$ clockwise rotation of the Philippine Sea Plate since the Oligocene. In this paper, however, modern geographic coordinates are used for features in the Izu-Bonin area because the rotation has not affected the relative positions of the arc, forearc basin, and trench.

The Oligocene basin fill thins from the vicinity of Site 787 to the vicinity of Site 793 (i.e., from north to south) above irregular basement, but then thickens southward toward the Bonin Trough west of the Bonin Islands (Honza and Tamaki, 1985; Taylor et al., 1990). Although holes at Sites 787, 792, and 793 were not drilled into the thickest areas, the uniform seismic character suggests that the oldest, unsampled forearc-basin deposits are similar to the drilled sections (Taylor et al., 1990). Water depths of about 3-4 km (Kaiho, this volume) prevailed on the elongate, Oligocene basin plain, which was devoid of large-scale channels or submarine valleys (Taylor et al., 1990; Klaus and Taylor, 1991).

Worldwide, sandy turbidite facies from intraoceanic forearc basins are poorly known. The Leg 126 results, therefore, are an important addition to global understanding of forearc sedimentology. As well as providing a fairly continuous core record, the Leg 126 forearc sites were the first ODP boreholes to be imaged by the Schlumberger formation microscanner tool (FMS). The combination of high-quality core and high-resolution electrical images has allowed us to construct long, bed-by-bed, sedimentary columns through two vertical sections of the forearc-basin fill. Such continuous vertical coverage is normally only available from detailed outcrop studies. Also, the spatially oriented FMS images have helped collection of the paleocurrent data presented in this paper, based on sandstone grain fabric and ripple migration directions.

Our aim in this paper is to provide a detailed description of the deep-water, Oligocene, volcaniclastic turbidite succession in the forearc basin. We first summarize the main lithologic characteristics of the 


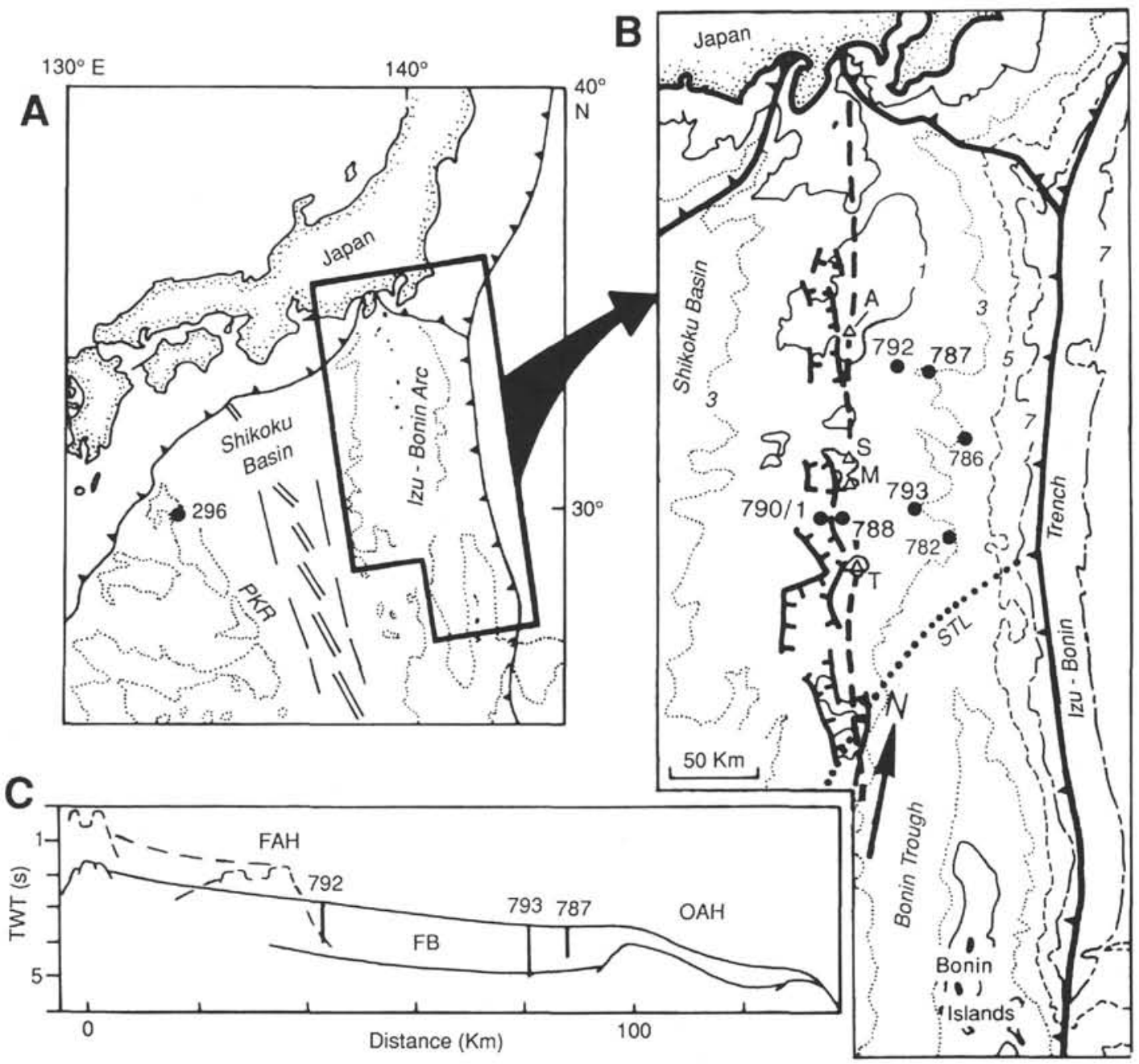

Figure 1. Location of drill sites. A. Position of the Izu-Bonin Arc at the eastern edge of the Philippine Sea Plate. DSDP Site 296 on the Palau-Kyushu Ridge (PKR) and the location of Figure 1B are indicated. The dotted lines mark $3 \mathrm{~km}$ water depth, the barbed lines are trenches, and the double lines indicate the extinct spreading center in the Shikoku Basin. B. Bathymetry, in thousands of meters, of the northern part of the Izu-Bonin Arc, from Honza and Tamaki (1985). Also shown are the location of Leg 126 Sites 787, 792, and 793, Leg 125 Sites 782 and 786, and the Sofugan Tectonic Line (STL; Yuasa, 1985). Trenches are indicated by barbed lines and backarc basins by hashured lines. The position of the modern volcanic front is marked by a heavy dashed line that passes, among others, through arc volcanoes Aogoshima (A), Sumisu Jima (S), Minami Sumisu Jima (M), and Torishima (T). C. Projection of the positions of the Leg 126 forearc-basin sites into a single synthetic cross section. FAH = frontal-arc high, FB $=$ forearc basin, $\mathrm{OAH}=$ outer-arc high, and TWT $=$ two-way traveltime. The dashed lines show the relief of the arc in the vicinity of Site 792, which is more rugged than the relief in a section that cuts through Site 793 (solid lines near the frontal-arc high).

complete succession and later emphasize the facies of the Oligocene turbidite package. These facies and their organization in vertical sections are illustrated with the aid of core photographs, FMS images, and detailed FMS-based sedimentary sections. Those parameters that were extracted with the help of FMS images (e.g., paleocurrent data, bed-thickness frequency distributions, and average recurrence intervals for sediment gravity flows) are given particular emphasis.

\section{GENERAL LITHOSTRATIGRAPHY OF THE FOREARC BASIN}

The basement to the forearc basin was cored at Sites 792 and 793 and consists of andesite and basaltic andesite (R. Taylor et al., this volume). Most of the overlying strata (Fig. 2) form a thick Oligocene turbidite succession deposited at undecompacted rates of 100-300 $\mathrm{m} / \mathrm{m} . \mathrm{y}$. (Taylor, Fujioka, et al., 1990; all rates in this paper are uncorrected for postdepositional compaction). The oldest recovered sedimentary rocks from the turbidite succession (about $31 \mathrm{Ma}$ ) are at Sites 792 and 793. Site 792 is located on a basement high where an unconformity (about 715 mbsf; Taylor et al., 1990) developed early in the history of basin filling. During the hiatus at Site 792, turbidites continued to be deposited at Site 793. Later, after about $29 \mathrm{Ma}$, Site 792 again began to receive continuous sedimentation. Only about $200 \mathrm{~m}$ of the Oligocene turbidite section was cored at Site 787; there, the oldest sedimentary rocks recovered have an age of about $29 \mathrm{Ma}$.

All three forearc sites have fairly complete records of late Oligocene sedimentation (about 29-24 Ma). The facies in this part of the section are mainly turbidites and submarine debris-flow deposits; these are described in detail below. In general, the coarse-grained, thick-bedded sandstones, pebbly sandstones and conglomerates are older than about 28.0-27.5 Ma. Deposits that formed in the latest Oligocene (about 27-24 Ma) are generally finer grained and bur- 
Site 792

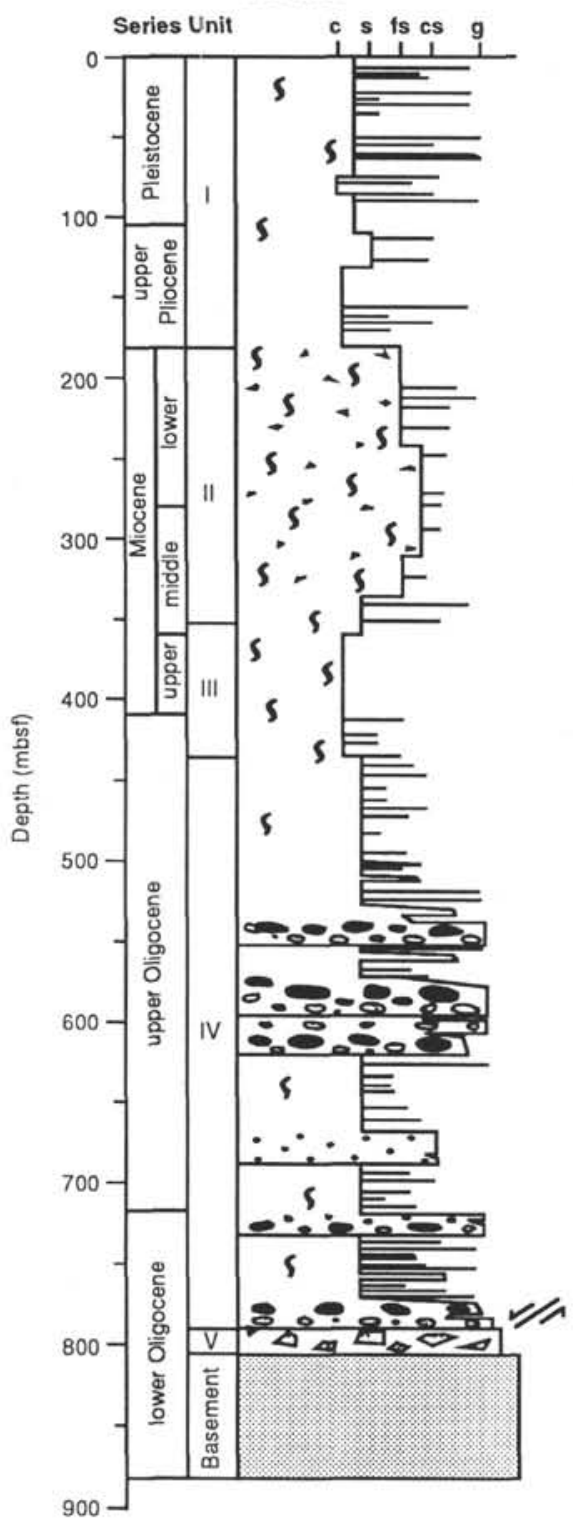

Key to graphic lithology

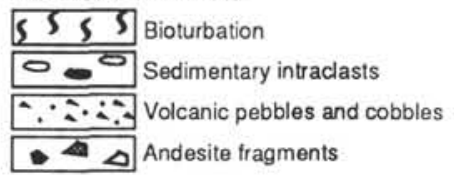

Site 793

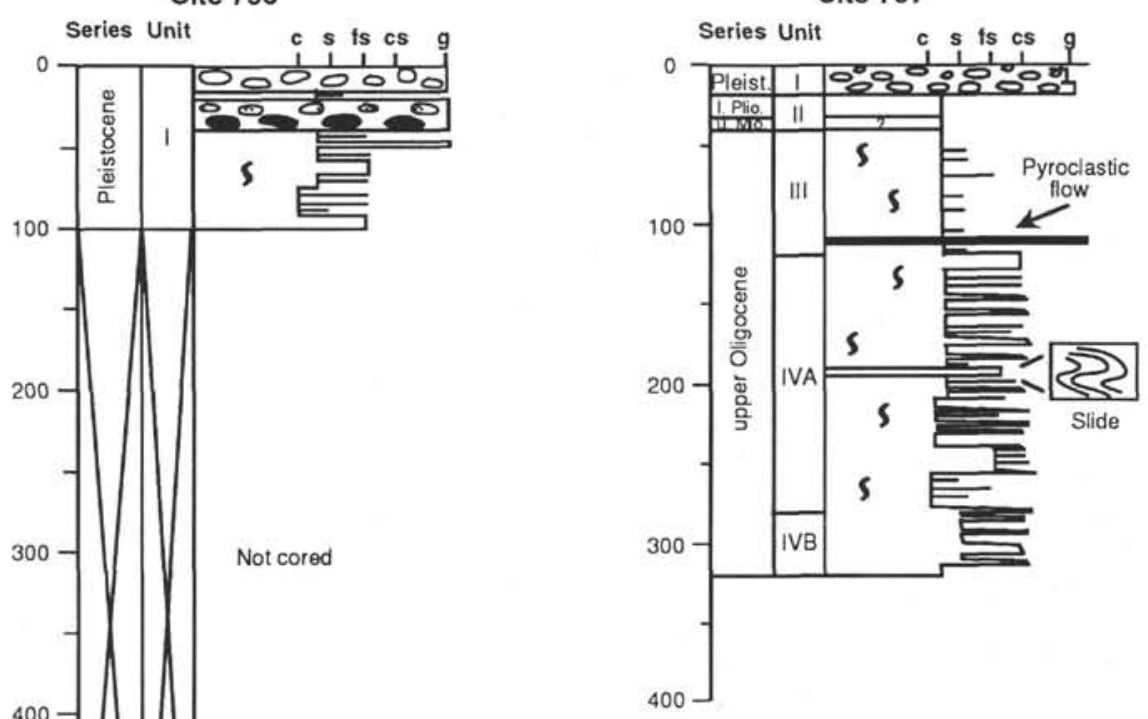

Site 787

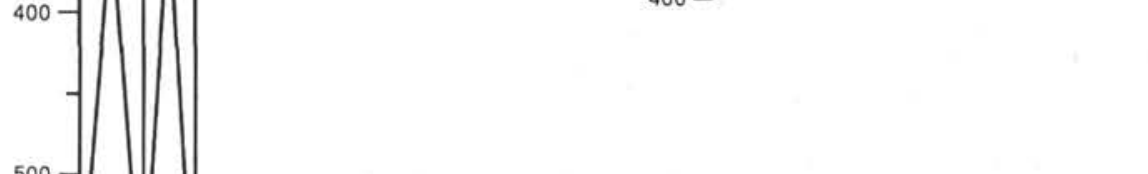

Site 793 (cont.)

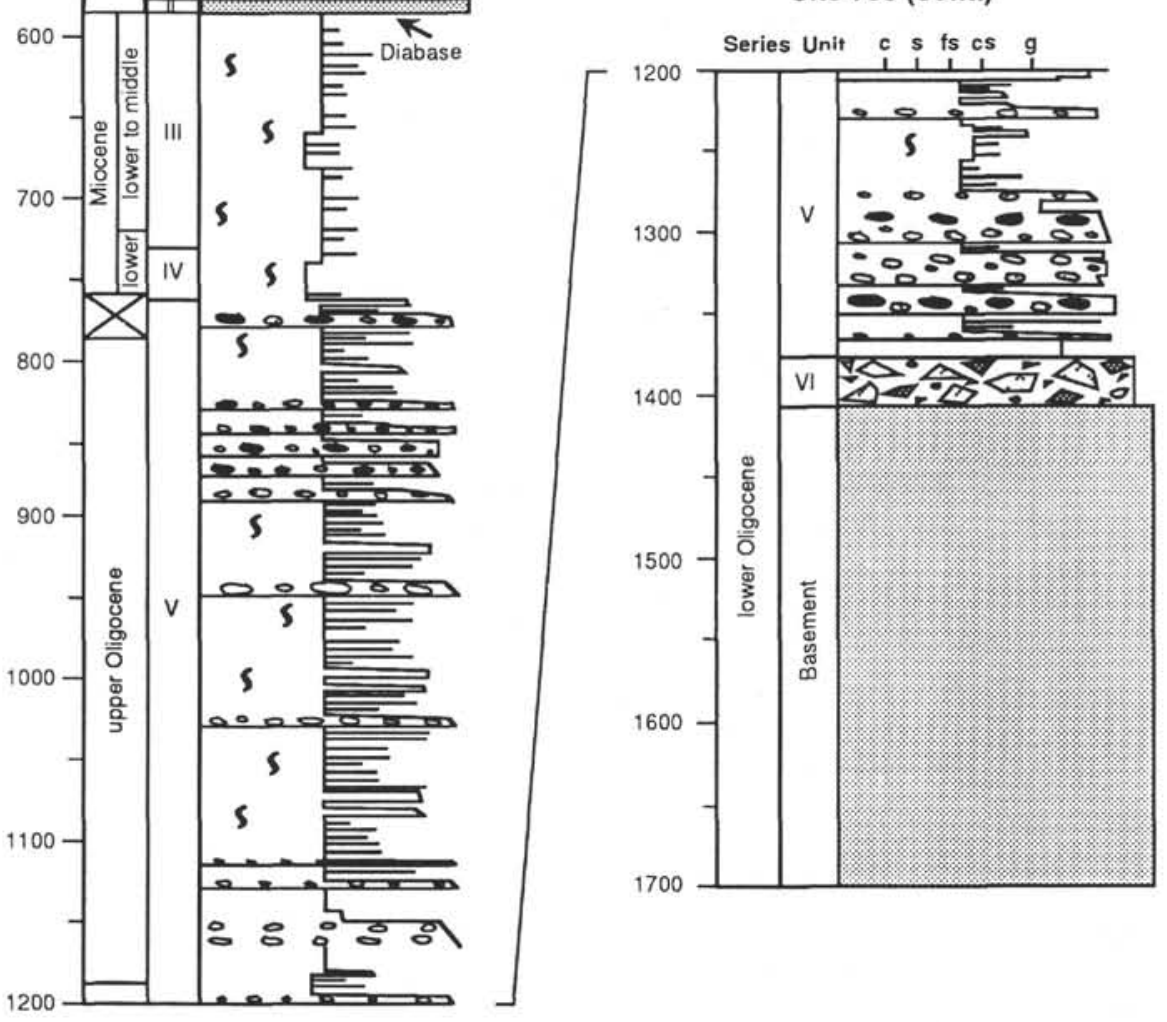

Figure 2. Graphic sections for forearc Sites 787, 792, and 793. The units are those of Taylor, Fujioka, et al. (1990). Letter symbols are as follows: $\mathrm{c}=$ clay/claystone, $\mathrm{s}=$ silt/siltstone, $\mathrm{fs}=$ fine-grained sand/sandstone, $\mathrm{cs}=$ coarse-grained sand/sandstone, and $\mathrm{g}=$ gravel/conglomerate. The visually determined grain size is thought to be about the 10 th percentile of the size distribution in these poorly sorted sedimentary rocks. 
rowed, and locally contain $10 \%-30 \%$ nannofossils; sedimentation rates at this time were $<20 \mathrm{~m} / \mathrm{m}$.y.

The lower to middle Miocene of the forearc is represented by fine-grained, deep-water sediments, most of which are rich in biogenic carbonate (Taylor, Fujioka, et al., 1990). In general, the only significant terrigenous component in the sediments is clay. The total section of this age is thin because of low sedimentation rates and multiple unconformities. Sedimentation rates ranged from 5 to 15 $\mathrm{m} / \mathrm{m}$.y. during the early to middle Miocene.

Sediments of late middle Miocene and late Miocene age were only recovered at Site 792, where they consist mainly of strongly burrowed sandy mudstone and muddy sandstone with nannofossilrich intervals. The disseminated sand and silt grains are mainly brown scoria, clear volcanic glass shards, and other volcanic rock fragments. These coarser components represent volcanic ejecta that accumulated slowly and were mixed into the surrounding sediments by burrowers (Colella et al., this volume).

The Pliocene and Pleistocene sections at the three forearc sites are dissimilar to one another in lithology and depositional processes. At Sites 787 and 793, sediments of this age were deposited in deep-sea valleys cut into the forearc-basin deposits, and consist, in whole or in part, of mixtures of pumiceous and scoriaceous sand and gravel. Site 792 penetrated a sheetlike, Pliocene and Pleistocene, fine-grained section of predominantly nannofossil-rich clayey silt and nannofossil-rich silty clay with scattered graded interbeds of vitric silt, vitric sand, and minor scoriaceous and pumiceous gravel that are interpreted as primary or resedimented volcanic ash.

\section{THE FORMATION MICROSCANNER}

\section{Instrumentation and Processing}

The formation microscanner (Schlumberger trademark) creates a picture of the borehole wall by mapping its resistivity using an array of small, pad-mounted electrodes (Lüthi and Banavar, 1988). The configuration developed for ODP (Shipboard Scientific Party, 1990; Pezard et al., 1990; Pezard and Lovell, this volume) uses four pads, each with 16 buttons; a single pass of the tool maps about $30 \%$ of the 25.4-cm-diameter borehole. During logging, current flows from the lower section of the tool into the rock. Some of the current flows from the buttons on the pads to a return electrode located at the top of the sonde. Because of the electrode geometry, the tool has a moderately shallow depth of investigation (a few centimeters beyond the borehole wall). The button current is recorded as a series of curves that represent relative changes in microresistivity caused by either (1) varying electrolytic conduction as a function of fluid type, and changes in pore and grain volume, size, and geometry, or (2) cation exchange on the surfaces of clay minerals and other conductive minerals (Bourke et al., 1989). The current intensity measurements are converted to variable-intensity gray or color images. In the former, black is lowest resistivity and white is highest resistivity. FMS data are recorded each $2.5 \mathrm{~mm}$, as the tool moves up the borehole; vertical resolution of individual structures and features is about $10 \times$ this value, or $2.5 \mathrm{~cm}$. The tool can, however, detect thinner features provided they have sufficient resistivity contrast with their surroundings.

Data processing includes conversion of the current intensity to variable-intensity images. Only 16 gray or color scales are represented in hard copies of the images, whereas the Schlumberger workstation used to evaluate the Leg 126 images subdivides the image into about 256 colors and shades, providing much better resolution of structures in the rocks. The images presented in this paper, therefore, are of lower quality than those that were used to collect orientation data at the Schlumberger workstation in Dallas, Texas.

\section{Generation of Sedimentary Sections}

The intervals that were successfully logged with the FMS tool are 2083-2448 m below rig floor (mbrf) in Hole 792E, and 3562-3739 and 4009-4514 mbrf in Hole 793B. Our analysis of these data is restricted to the Oligocene sections and to runs of data uncomplicated by poor image quality. The rest of this paper, therefore, deals only with FMS data from depths of 2232-2441 mbrf in Hole 792E and 4023-4330 mbrf in Hole 793B. The locations of these intervals relative to core numbers and depths in meters below seafloor (mbsf) are given in Figure 3.

For rocks of similar mineralogy, cementation, and fluid type, the pixel tone on the FMS images is a function of grain size, with the darker tones corresponding to finer grained sedimentary rock. At a superficial level, therefore, the FMS images provide a strip record of texture and sharpness of contacts between beds of different grain size. The approximate correspondence between beds in FMS images and equivalent beds in cores was obtained by converting log depths, below rig floor, to core depths, below seafloor, by subtracting 1798.2 and $2975.3 \mathrm{~m}$ for Holes 792E and 793B, respectively. The thicker, and therefore more unique, sandstone beds in cores could be matched, in most cases, with the same beds in the FMS images, where the sandstones appear light in tone. Based on these first matches between cores and FMS images, the lightness of the tone on the images was calibrated against the grain size reported in shipboard visual descriptions, which in these poorly sorted deposits is thought to be about the 10 th percentile of the size distribution. Then, thinner beds were matched, where possible, between the core descriptions or photographs, and the FMS records, using distinctive sequences of beds and bed thicknesses. This was done for all recognizable beds, including those with thicknesses on the order of about $1 \mathrm{~cm}$. For parts of the succession where core recovery was incomplete, the FMS images alone, combined with knowledge of the correspondence in nearby rocks between grain size and image tone, were used to construct the bed-by-bed sections of Figures 4 and 5 (back-pocket figures). The depths, in mbrf, of all bed contacts were entered into a computer data file, and the sedimentary logs were plotted using the computerized graphics package AutoCad. The total number of sharp-based sandstone beds recorded in the FMS sections for Holes 792E (2232-2441 mbrf) and 793B (4023-4330 mbrf), respectively, are 447 and 807.

On Figures 4 and 5 (back-pocket figures), the positions of core tops, from drilling records, and matches between visual descriptions and FMS $\log$ depths are indicated. Sedimentary structures and large clasts, most of which can be recognized on the FMS images and confirmed by examination of core photographs and shipboard visual descriptions, are included for the thicker sandstone beds. Only fluid-escape structures, which are recognized on the basis of very subtle textural contrasts, were seen only in the cores. Ages marked beside the columns come from the age-depth plots in Taylor, Fujioka, et al. (1990).

There is a remarkable similarity between the FMS-based sedimentary logs and the resistivity data gathered during other logging runs (Taylor, Fujioka, et al., 1990, pp. 291-292 and 398-400). From $4030-4050$ mbrf in Hole 793B, each increase in resistivity corresponds to an increase in grain size observed in the core. The most spectacular example of this relationship is the thick debris-flow deposit with base at $4090 \mathrm{mbrf}$ (Hole 793B); this bed has a sharp basal contact in the FMS data, and a gradational transition to more conductive deposits with finer grain sizes toward the top. It is useful to know that the resistivity data so accurately reflect the combined FMS and core data, because the more conventional logs cover a greater range of depth. There is now some justification for using the resistivity log in these forearc-basin deposits to infer details about depositional processes in sections not imaged by the FMS tool.

\section{TURBIDITE AND RELATED FACIES}

No FMS logs were obtained from Site 787 , which also failed to penetrate into the lower part of the forearc-basin fill. Therefore, we have chosen to emphasize data from Sites 792 and 793. Generalized sedimentary logs for the Oligocene sections cored at these sites are presented in Figure 3, together with (1) the locations of high-quality 

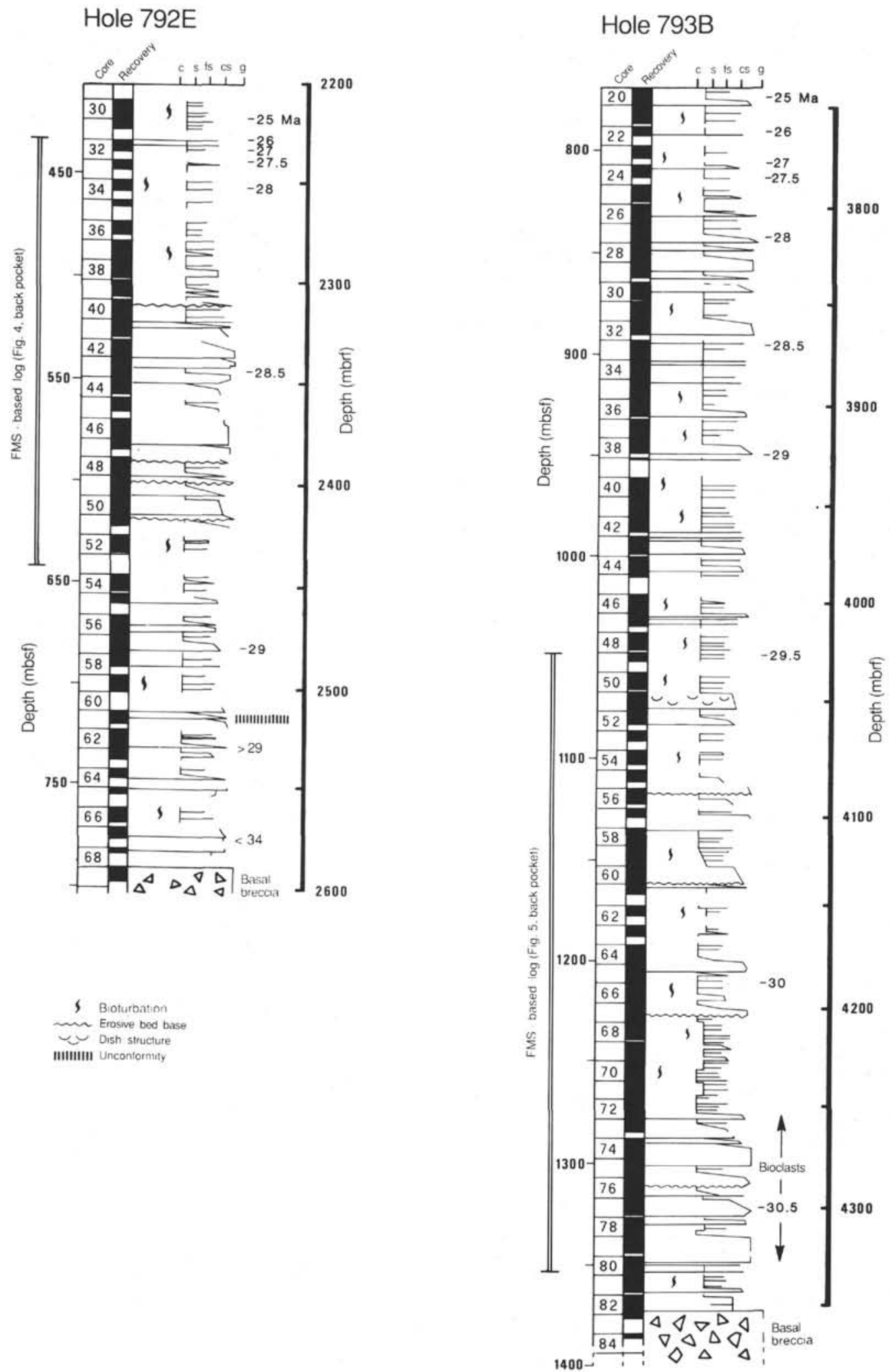

Figure 3. Simplified columns, based on core descriptions, for Holes 792E and 793B. The columns indicate visually determined grain size (thought to be about the tenth percentile of the size distribution in these poorly sorted sedimentary rocks), bedding characteristics, occurrences of large bioclasts, core numbers, recovery, depths below rig floor (mbrf) and the sea bed (mbsf), selected age picks (e.g., $27 \mathrm{Ma}$ ), and the location of the FMS-based logs of Figures 4 and 5 (back-pocket figures). Letter symbols are as in Figure 2. Information is only shown where there was core recovery; therefore, there are many gaps in both columns. 
FMS images; (2) selected age picks based on the age-depth plots in Taylor, Fujioka, et al. (1990); (3) core numbers; and (4) core recovery. Note that the top of the FMS-based section at Hole 793B is older than the base of the FMS-based section at Hole 792E. Sedimentary rocks with ages from 29.5 to $28 \mathrm{Ma}$ at Site 792 were deposited at higher accumulation rates than contemporaneous strata at Site 793 .

The parameters used to distinguish the sedimentary facies described below are grain size, bed thickness (classes of Ingram, 1954), and sedimentary structures. Bed thicknesses for the thickest beds cannot be obtained from cores, because single depositional units commonly span cored intervals, and any missing material at the boundaries between these cores could contain bed boundaries or amalgamation surfaces. Continuous FMS images (Figs. 4 and 5, back pocket) do not have this limitation. Postdepositional features (e.g., clastic injections and fractures) are described in Taylor, Fujioka, et al. (1990).

\section{Mudrocks}

Mudrocks generally occur as thin interbeds between coarser grained units; the upper $80 \mathrm{~m}$ of the Oligocene section at Site 787 (deposited from 27 to $23.5 \mathrm{Ma}$ ) is anomalous in that it is mainly mudstone without sandstone interbeds. Mudrocks form 5\% and $10 \%$ of the FMS-based sections from Holes 792E and 793B, respectively. The silicate fraction has the chemical attributes of volcanic material (Nishimura et al., this volume). The $\mathrm{CaCO}_{3}$ content (mainly nannofossils) ranges from $0 \%$ to $50 \%$ at Site 787 and 792, whereas the interbeds at Site 793 contain very little carbonate. The higher $\mathrm{CaCO}_{3}$ contents characterize (1) strata deposited when sediment accumulation rates were lowest (e.g., from 27 to 23.5 Ma) and (2) most of the Site 787 section (rates $<100 \mathrm{~m} / \mathrm{m}$.y.; Taylor, Fujioka, et al., 1990).

Mudrocks are finely laminated in some cases, but they are generally variably burrow-mottled. The most intense bioturbation is associated with the highest $\mathrm{CaCO}_{3}$ contents and the lowest sedimentation rates. The burrows penetrate into underlying siltstone or sandstone beds.

\section{Graded Siltstone Beds}

Siltstone, which occurs mainly as very thin to thin graded beds, forms $11 \%$ and $8.3 \%$ of the FMS-based logs for Holes 792E and 793B, respectively. The beds have sharp bases, and are parallel laminated and/or cross laminated (Bouma, 1962, divisions b, c, and d).

\section{Very Thin and Thin, Graded Sandstone Beds}

Very thin and thin, graded beds, with bases of generally very fine-grained to fine-grained sandstone, form $4 \%$ and $7 \%$ of the FMS-based sections at Holes 792E and 793B, respectively. Bouma sequences prevail (Figs. 6 and 7). Except for a coarser grain size, these beds are similar in appearance to many of the graded siltstone beds. One flute cast was observed in the cores (Fig. 8A).

\section{Medium and Thick, Graded Sandstone Beds}

Medium and thick graded beds, with bases of generally fine- to coarse-grained sandstone, form $36 \%$ and $30 \%$ of the FMS-based sections at Holes 792E and 793B, respectively. Bouma sequences are the norm (Fig. 9); most of the thicker beds have a basal division that is structureless (Bouma, 1962, division a) or parallel laminated (division b; Fig. 10). One flute cast was observed (Fig. 8B).

\section{Very Thick Sandstones, Granule Sandstones, and Pebbly Sandstones}

Most beds of this facies consist of medium- to coarse-grained sand (Figs. 4 and 5, back pocket). Some of the beds have conglomeratic basal divisions; we arbitrarily restrict this facies to beds with $<1 \mathrm{~m}$ of

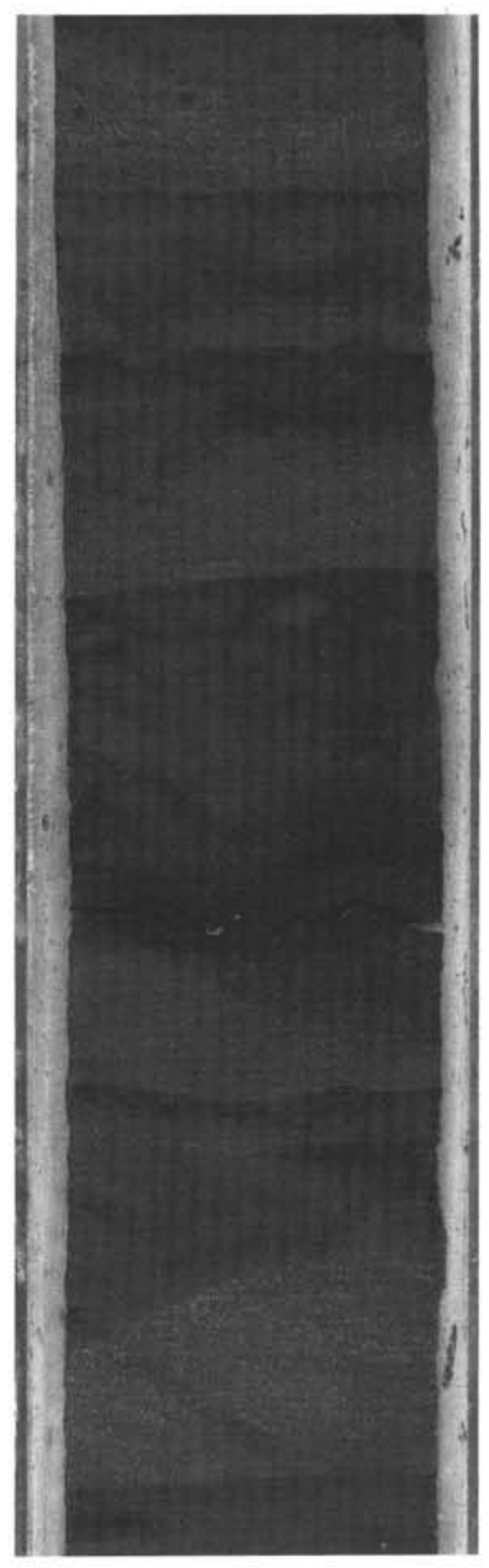

Figure 6. Core photograph of an interval consisting of five graded beds of very fine-grained sandstone with parallel or cross lamination (Sample 126-792E$38 \mathrm{R}-1,20-44 \mathrm{~cm})$. Only the tops of these units are burrowed. The FMS images of cross lamination in this part of the section were used to obtain paleocurrent data. Width of core liner is $6.5 \mathrm{~cm}$.

conglomerate. Basal erosional relief of a few centimeters can be seen in some cores and FMS images. Beds of this facies form $34 \%$ and $38 \%$ of the FMS-based sections at Holes 792E and 793B, respectively. At both holes, a few exceptional beds $>10$-m-thick account for a significant part of the section.

Essentially all beds thinner than $3 \mathrm{~m}$, and some beds that are as thick as about $10 \mathrm{~m}$, are normally graded throughout, with tractional structures like parallel lamination and cross lamination in their upper parts. Based on visual examination, other beds, generally thicker than $3 \mathrm{~m}$, are characterized by very poor sorting, poorly developed clast fabric, and poorly developed normal grading that, if present, is restricted to the top of the bed. These beds may contain upper divisions of parallel or ripple lamination, and concentrations of pebble 


\section{Azimuth}

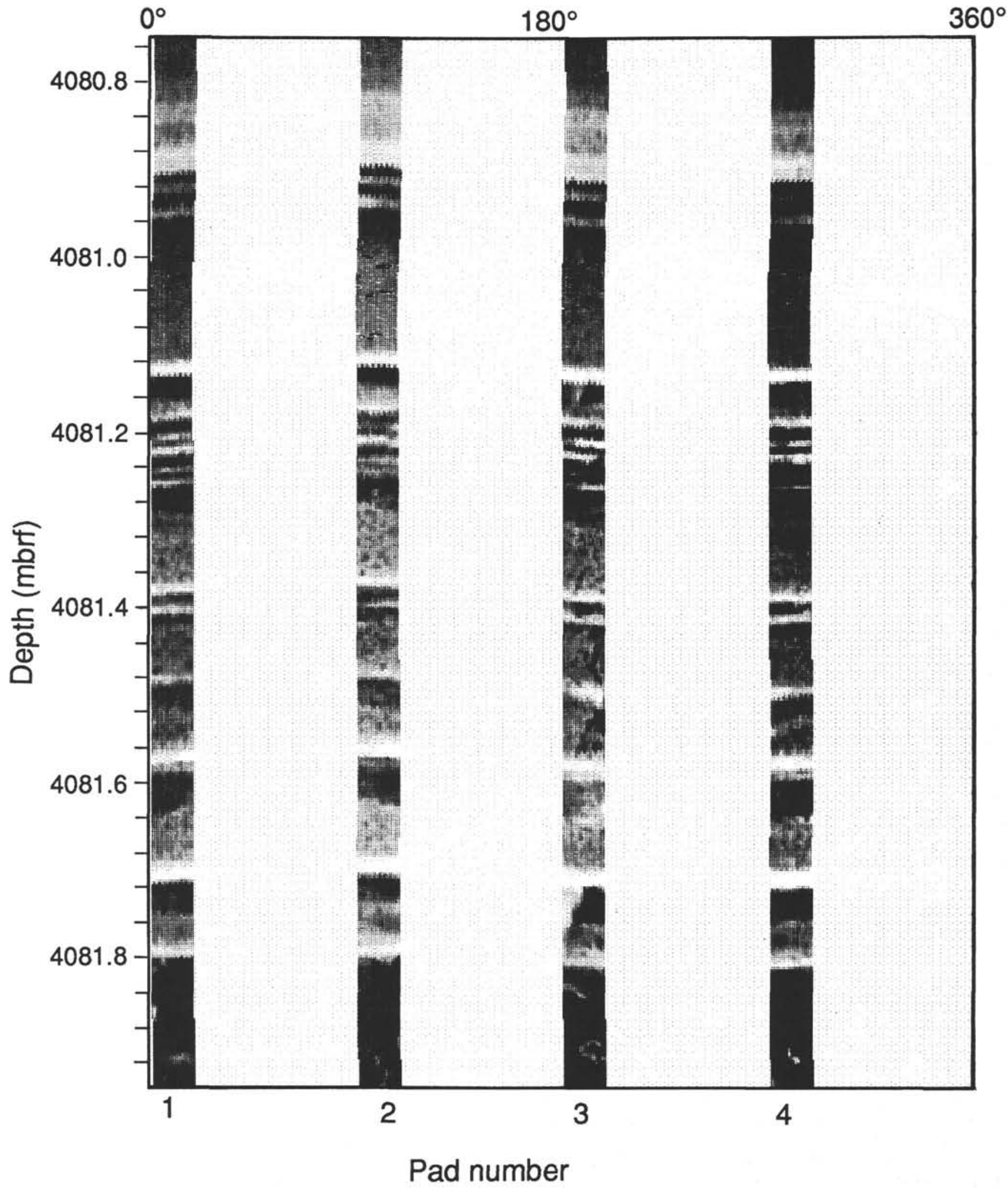

Figure 7. FMS image of very thin and thin, sharp based, graded beds from Hole 793B. Lighter tones indicate coarser grained sediment. Dark vertical features in Pad 3 image are fractures. 


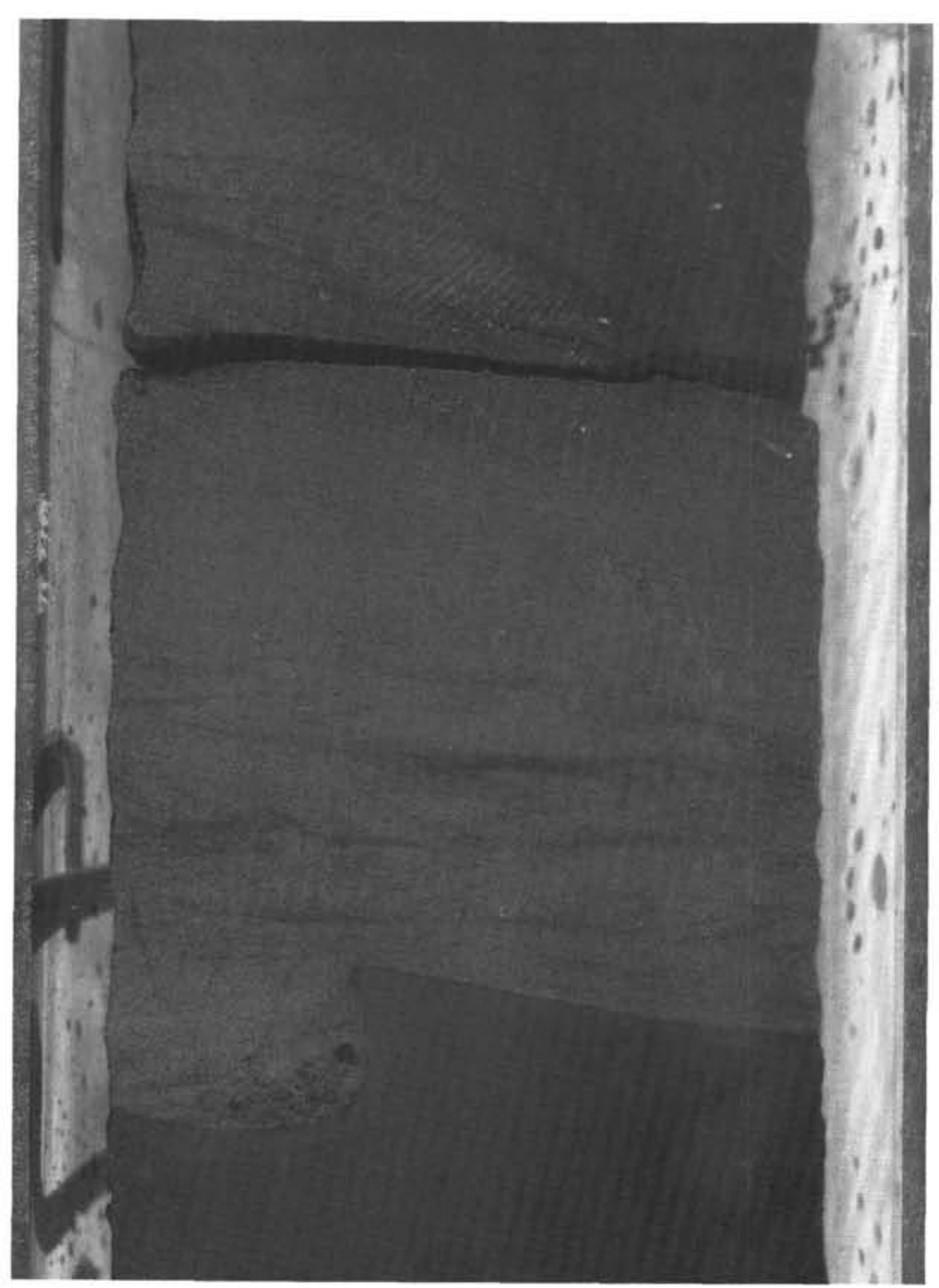

A

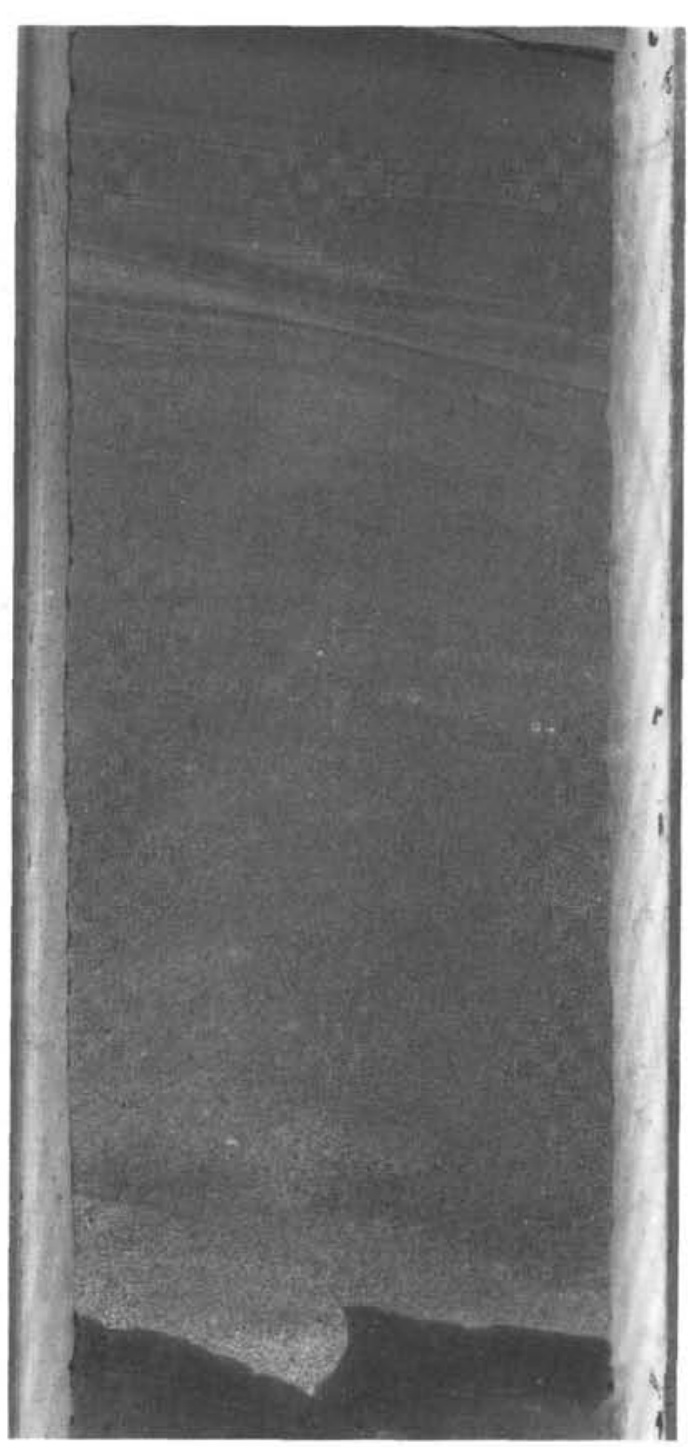

B

Figure 8. Flute casts on the bases of sandstone beds. Width of core liners is $6.5 \mathrm{~cm}$. A. Nose of a flute cast on the base of a thin bed of graded, fine-grained sandstone (Sample 126-793B-47R-3, 6-16 cm). Note the accumulation of coarse and very coarse sand grains at the upstream end of the flute cast. Ripple lamination in the sandstone bed confirms that flow was from right to left. The bands in the shale, parallel to the margin of the flute, are diagenetic. B. Medium bed of graded, mediumto fine-grained sandstone with a cross-laminated top and a basal flute cast (Sample 126-792E-48R-4, 5-24 cm).

to boulder intraclasts either near, or well above, the base of the bed (Figs. 11 and 12). Some beds have interior divisions of subtle, widely spaced stratification like that described by Hiscott and Middleton (1979); each stratification band has an inversely graded base even though the entire bed may be normally graded. One bed at about 4045 mbrf in Hole 793B (Fig. 5, back pocket) contains dish structures throughout and fluid-escape pillars in its upper part. A few beds have an inversely graded base (e.g., Fig. 4, back pocket, 2423 mbrf; Fig. 5, back pocket, $4048,4161,4217,4286,4300$, and $4326 \mathrm{mbrf}$ ).

The intraclasts range in lithology from mudstone to fine-grained sandstone. Some clasts are deformed in a plastic manner. Nannofossils in a selection of 34 clasts have the same age as the surrounding sediments (J. Firth, pers. comm., 1990).

An interval at Site 793 from about 900 to 1020 mbsf, just above the depths of the FMS-based log, is characterized by large quantities of pumice, as coarse sand grains to granules, in sandstone beds. The pumice tends to occur well above the base of the beds as concentrated bands in parallel-laminated sandstone. In many beds, the increase in pumice size and abundance away from the base of the bed produces inverse grading.

Pebbly sandstone beds contain both volcanic and carbonate pebbles, many of the latter as individual fossils. These same clasts appear in the pebble conglomerates and are described in the next section. The carbonate clasts are only present in beds below about $1175 \mathrm{mbsf}$ in Hole 793B (Core 126-793B-62R; older than about 29.8 Ma).

\section{Conglomerates}

Conglomerates form about $10 \%$ of the Oligocene sections at Sites 792 and 793, and about the same amount of basal Subunit IVB at Site 787 (Taylor, Fujioka, et al., 1990). Some very thick sandstone and pebbly sandstone beds have thin, basal, conglomerate divisions that we omit from the conglomerate facies. Considering only the 10 beds that have conglomerate horizons $>1 \mathrm{~m}$ thick, or that are thinner but entirely conglomerate, the FMS-based logs (Figs. 4 and 5, back pocket) contain $10 \%$ and $7 \%$ conglomeratic beds in Holes $792 \mathrm{E}$ and 


\section{Azimuth}

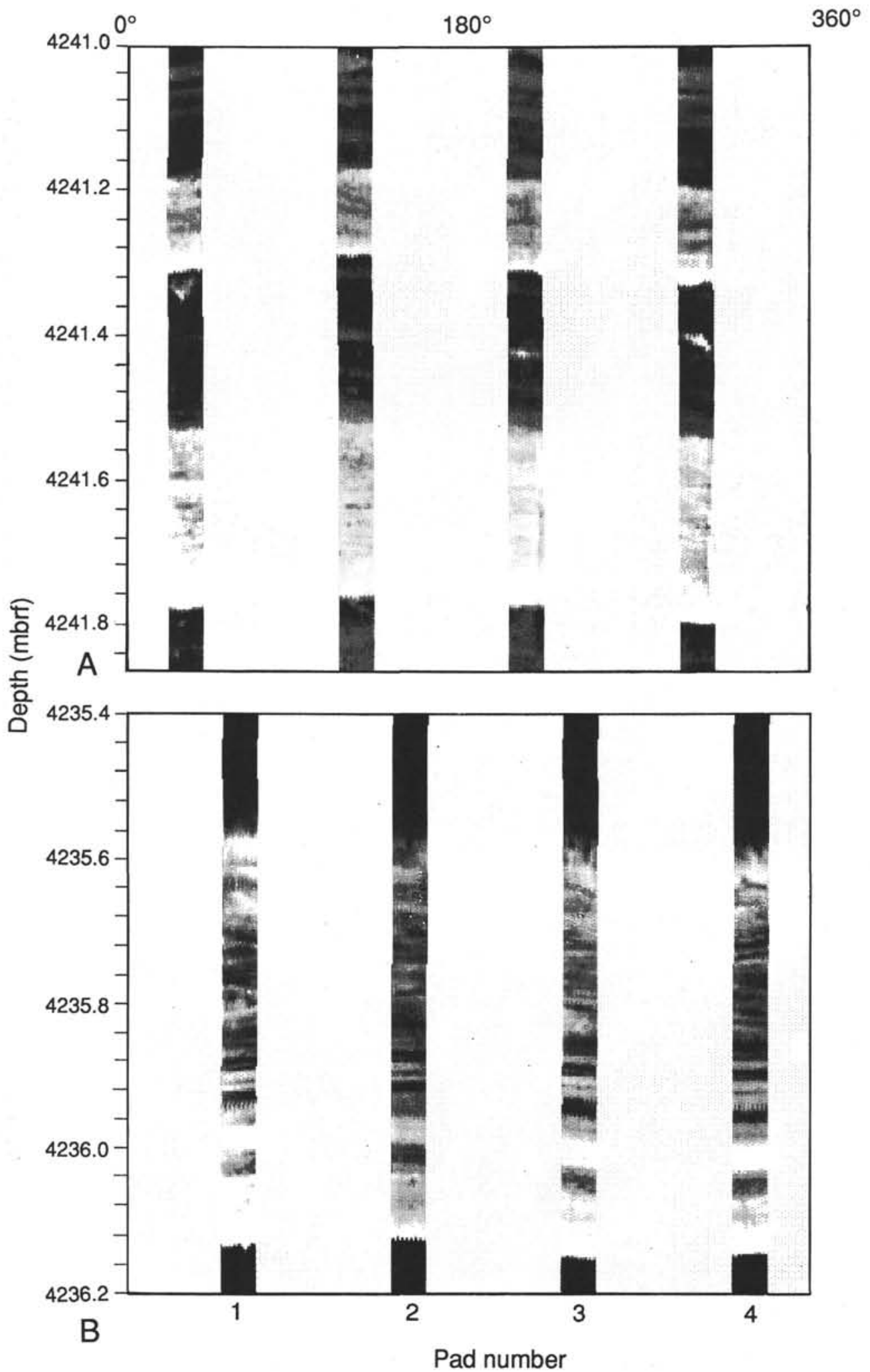

Figure 9. FMS images of sedimentary structures and grading in medium to thick sandstone beds in Hole 793B. Lighter tones indicate coarser grained sediment. A. Two graded beds, both cross laminated. The cross lamination is most visible in the upper bed at 4241.25 mbrf. B. Parallel lamination and wavy lamination in a sharp-based, graded sandstone bed. 


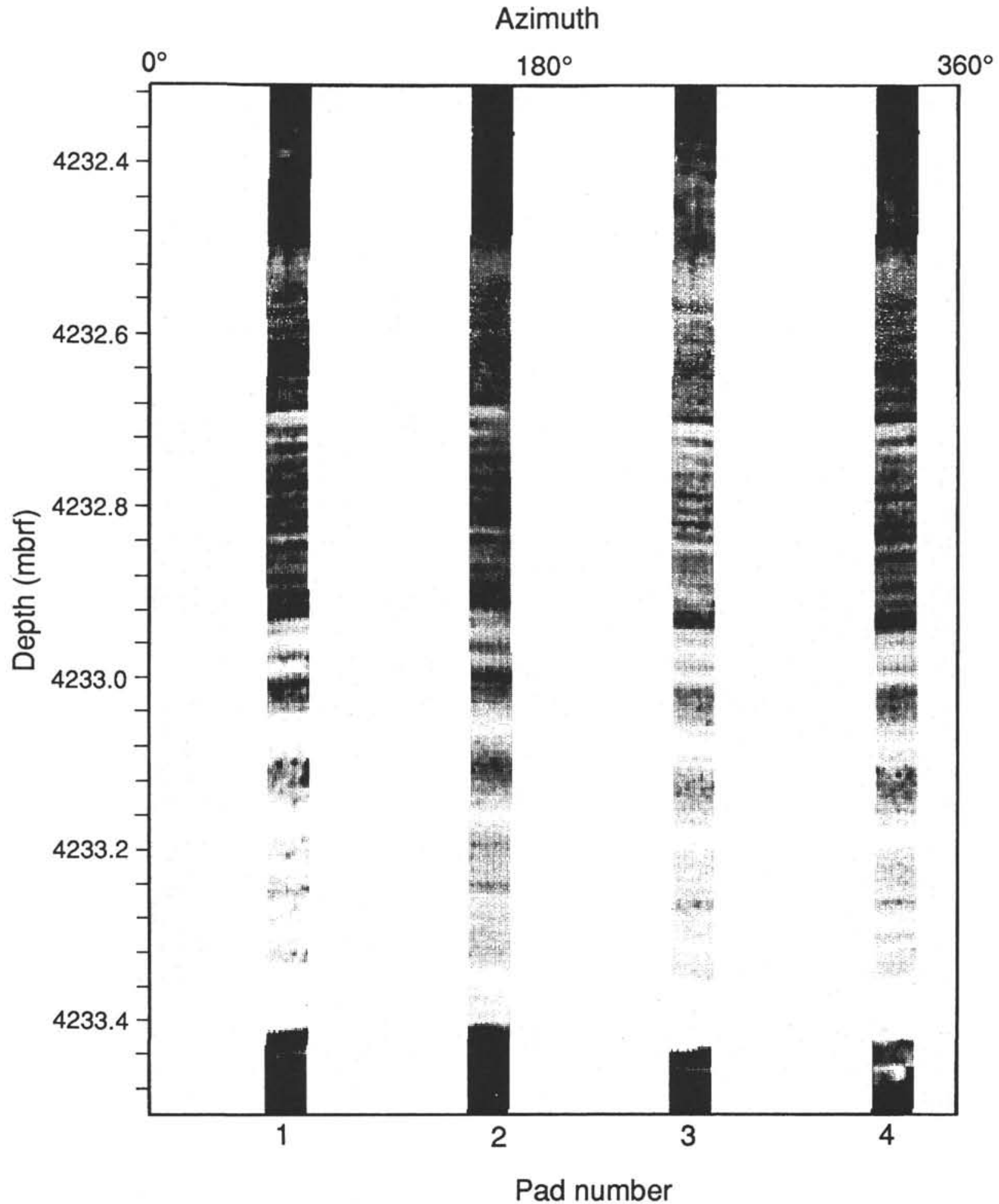

Figure 10. FMS image of a single, thick, parallel laminated, graded sandstone bed in Hole 793B, with its base at 4233.4 mbrf and its top at 4232.4 mbrf. Lighter tones indicate coarser grained sediment.

793B, respectively, similar to shipboard estimates. Several of these beds, however, grade upward into a sandstone part that is thicker than the conglomeratic part (e.g., Fig. 4, 2327-2337 mbrf, and Fig. 5, 4173-4180 mbrf; back pocket figures). Of the 10 beds, three are ungraded (two of these are $>1 \mathrm{~m}$ thick), three are inverse to normally graded, two are normally graded only, one is graded-stratified, and one is graded-stratified with basal inverse grading. In all cases, the stratification is parallel to bedding. In beds that grade into sand, the upper parallel lamination is identical to Bouma's (1962) division b.

The visual estimates of the grain sizes of the conglomeratic parts of the beds range from fine pebbles to granules. These horizons are devoid of tractional structures. There are local concentrations of fine-grained, mainly mudstone, cobble and boulder intraclasts like those in the very thick bedded sandstones. Volcanic clasts include 


\section{Azimuth}

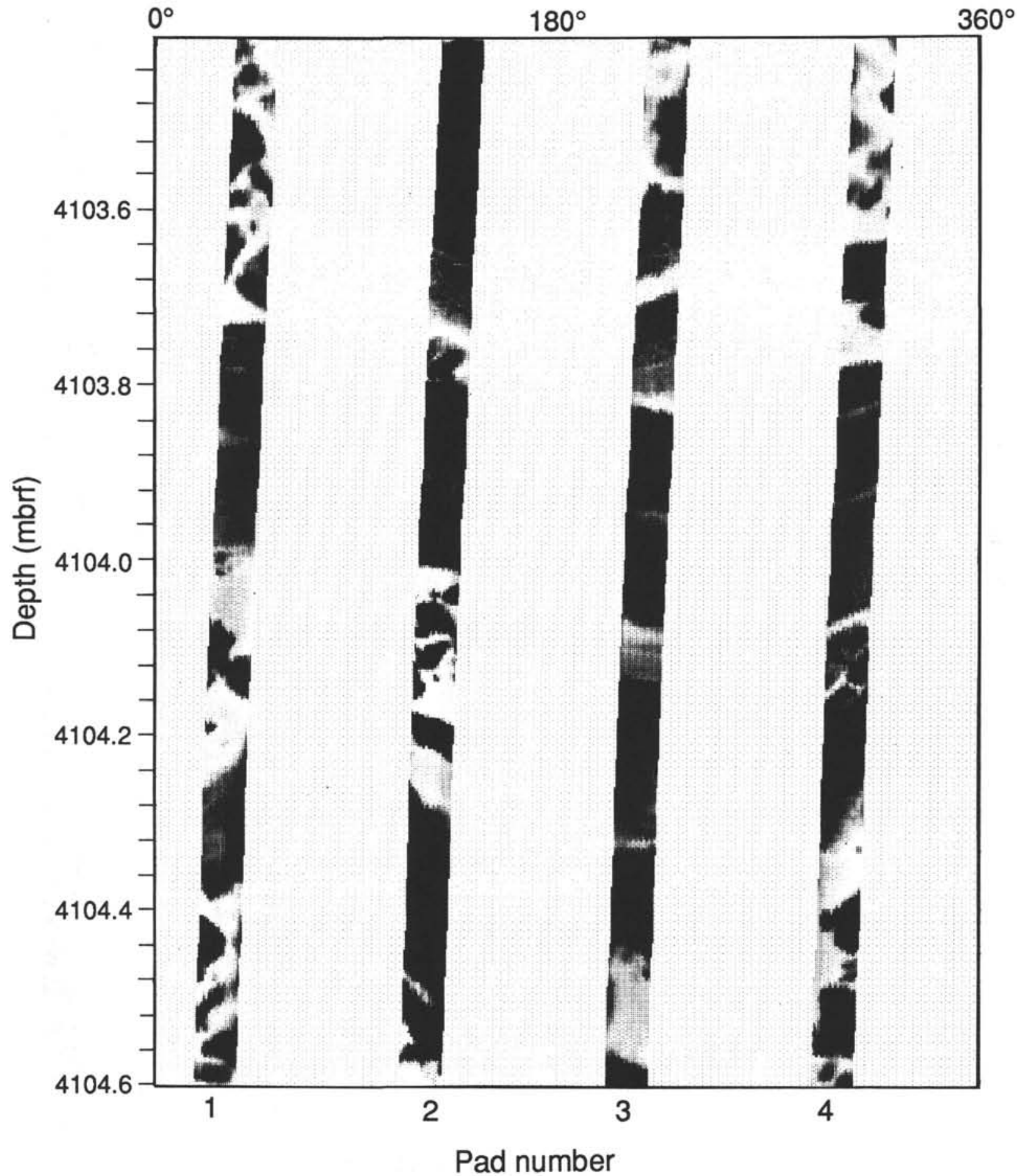

Figure 11. FMS image of pebble- to boulder-sized mud clasts in a 4-m-thick bed of coarse-grained sandstone in Hole 793B. Some of the clasts are laminated. Lighter tones indicate coarser grained sediment. 


\section{Azimuth}

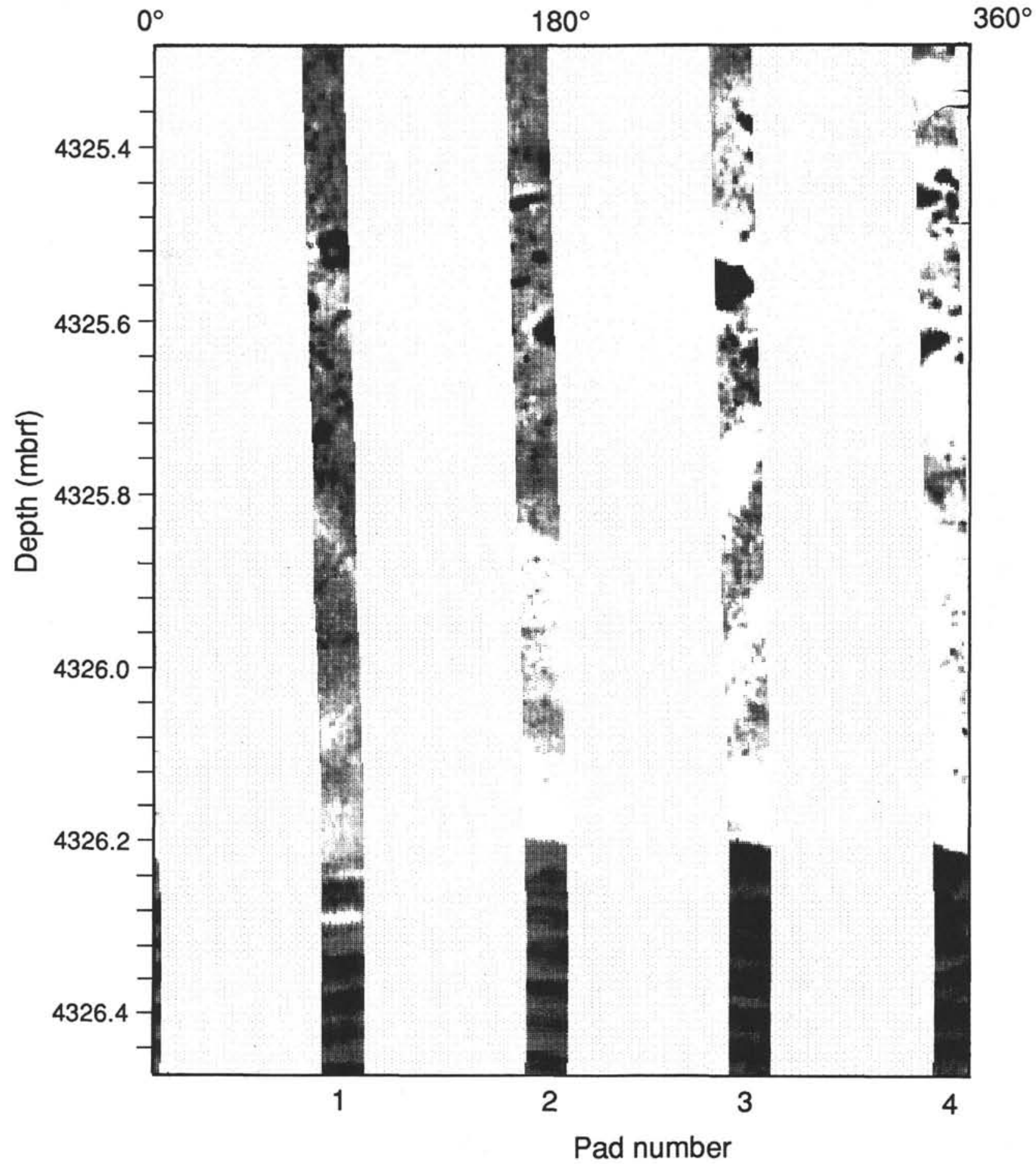

Figure 12. FMS image of the inversely graded base of a 1.5-m-thick, pebbly, granule sandstone in Hole 793B. The speckled character of the images above about $4326 \mathrm{mbrf}$ is a result of the coarser grain size. The dark objects at about $4325.6 \mathrm{mbrf}$ are mudstone clasts. The underlying sediment consists of very thin bedded, graded, siltstone beds. Lighter tones indicate coarser grained sediment. 


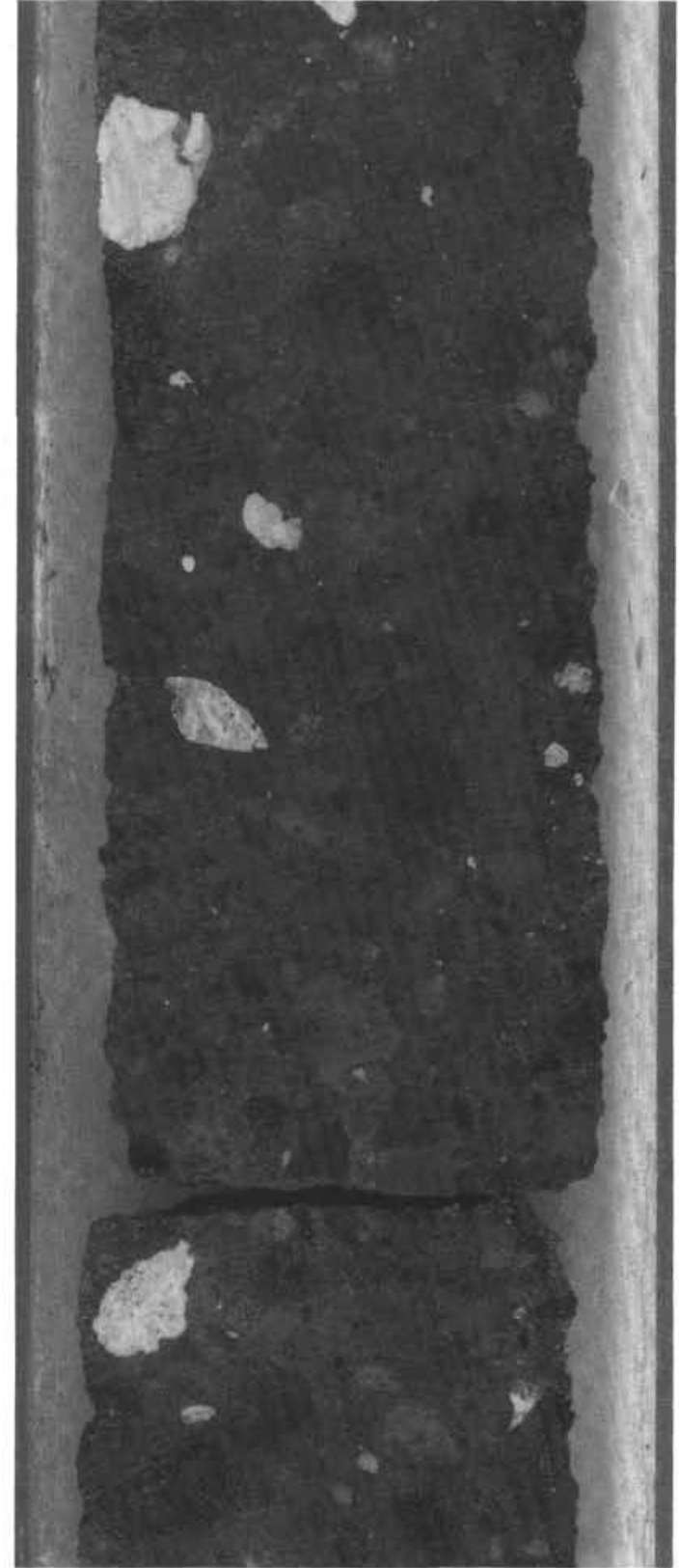

Figure 13. Core photograph of a volcanic-lithic conglomerate with large bioclasts of calcareous red algae (Sample 126-793B-75R-2, 83-100 cm). Width of core liner is $6.5 \mathrm{~cm}$.

andesite, dacite, basalt, brick red rhyolite with quartz phenocrysts, white and red pumice, and basaltic scoria (Taylor, Fujioka, et al., 1990). The beds below Core 126-793B-62R (about 4160 mbrf) contain scattered, resedimented benthic foraminifers as large as about $5 \mathrm{~mm}$ in diameter, and bioclast pebbles (Fig. 13), as large as $2 \mathrm{~cm}$ in diameter, of calcareous red algae, bryozoans, rare coral-bearing limestone, and lithified algal micrite (Nishimura, this volume). Some of the algae are Biplanispira mirabilis of probable middle to late Eocene age (Matsumaru et al., this volume).

\section{Deformed Beds}

The Oligocene section at Site 787 contains a deformed interval, $5.6 \mathrm{~m}$ thick, in which $75 \%$ of the sediment is overturned, and two horizons of plastically folded sandy mudstone and clayey siltstone.
The deformed interval contains extensional microfaults and sandstone injections.

\section{Depositional Processes}

The structures and textures of all siltstones, sandstones, and conglomerates are consistent with deposition from sediment gravity flows, ranging in character from turbidity currents of both high and low concentration to debris flows (Pickering et al., 1989). These variably diluted the hemipelagic input of nannofossil-rich mud. Very little hemipelagic sediment is preserved where sedimentation rates exceeded about $250 \mathrm{~m} / \mathrm{m}$.y., probably because of resuspension by, and incorporation into, numerous turbidity currents. Where rates fell below about $100 \mathrm{~m} / \mathrm{m}$.y., most of the mudstone between deposits of sediment gravity flows is calcareous.

The graded sandstones with Bouma (1962) sequences, most pebbly sandstones, and graded to graded-stratified conglomerates were deposited by turbidity currents (e.g., Walker, 1975). The very thick, mainly structureless beds of sandstone, pebbly sandstone, and pebble conglomerate, characterized by poorly developed fabric and grading (Rodolfo and Arguden, this volume), local inverse grading, and large mudstone intraclasts well above the base of the bed, are interpreted as debris-flow deposits. They are similar to the sandy and gravelly debris-flow deposits described by Hiscott and Middleton (1979, 1980) and Walker (1975). Inverse grading, where present, indicates the importance of grain collisions as a mechanism of clast support just before deposition. We interpret the inversely graded beds as weakly cohesive or noncohesive debris-flow deposits, following the schemes of Shultz (1984) and Postma (1986).

There is no seismic evidence that the very thick beds of sandstone, pebbly sandstone, and conglomerate were deposited in major channels (Taylor et al., 1990; Klaus and Taylor, 1991). Locally abundant intraclasts and basal scouring, however, indicate minor, local erosion into contemporaneous fine-grained deposits. Very thick beds younger than about $30.0 \mathrm{Ma}$ are interbedded with thin- to medium-bedded turbidites and seem to represent unique, high-volume events rather than channel-fill deposits. Some of these events were debris flows that may have been generated by catastrophic failure of parts of the coarse-grained apron surrounding the arc volcanoes (cf. Moore et al., 1989).

The general setting, apparently devoid of major channels, is inferred to have been an oversupplied basin plain (Pickering, 1982), similar to the example described by Ricci Lucchi and Valmori (1980). This interpretation is supported by disperse paleocurrents (see below). Unlike some ancient basin plains (e.g., Hiscott et al., 1986; Ricci Lucchi and Valmori, 1980), the thickest beds do not have impressive mudstone caps that would indicate ponding of the dilute tails of the flows within a confined, or silled, basin

The deformed beds at Site 787 are attributed to wet sediment sliding. The high water contents that favor sliding were also responsible for the locally abundant clastic injection at all forearc sites (Taylor, Fujioka, et al., 1990). Other controls on sediment failure were probably seismic activity and bottom slopes of perhaps a few degrees across the margins of the forearc basin.

\section{Bed-thickness Statistics}

It is clear from a cursory examination of the FMS-based logs (Figs. 4 and 5 , back pocket) that the number of sandstone beds is inversely proportional to bed thickness (i.e., that there are many thin beds and few thick beds). An appropriate distribution function is a power law, in which the number $N(t)$ of beds with a thickness greater than $t$ is proportional to $t^{\mathrm{b}}$, where "b" is a positive constant. Many geological and geophysical quantities (e.g., earthquake magnitudes, volumes of volcanic eruptions) follow a power-law distribution (Turcotte, 1989). In fact, it has been proposed already that turbidite bed thicknesses are distributed in this way (Hsü, 1983). 
Figure 14 shows logarithmic plots of the number $N(t)$ of sandstone-shale couplets with a thickness $>t$ vs. $t$; plots using sandstone bed thickness (i.e., ignoring the mud overlying each sandstone bed) are essentially the same. The data come directly from the files that were used to generate the FMS-based sedimentary logs. In log-log space, a power-law distribution plots as a straight line with slope $b$. For data from both FMS-based sections, plots follow a straight line with a slope slightly $>1.0$ for bed thicknesses ranging over 3 orders of magnitude from $10 \mathrm{~cm}$ to more than $10 \mathrm{~m}$. For beds thinner than $10 \mathrm{~cm}$, the number of beds is smaller than what would be expected from extrapolation of the straight line defined by the thicker beds. This observation can be interpreted in two ways. First, it may be that there are truly fewer thin and very thin beds $(<10 \mathrm{~cm}$ thick) than predicted by a simple power law. Second, beds that are just thicker than the resolution limit of the FMS tool $(2.5 \mathrm{~cm})$ are probably occasionally not detected and counted. As the resolution limit is bound to have some influence on the measurements, we prefer the latter interpretation.

\section{Bed-thickness and Grain-size Trends}

Asymmetric sequences of bed thickness or grain size (i.e., upward thinning and thickening sequences, or upward fining and coarsening sequences), meters to tens of meters thick, have been ascribed to intrabasinal controls in deep-marine environments. Examples include claims of upward thinning and fining submarine channel fills, and upward thickening and coarsening fan-fringe and lobe deposits on submarine fans (Mutti and Ghibaudo, 1972; Ricci Lucchi, 1975). These asymmetric sequences are, in almost all cases, identified subjectively and, in some cases, sequences of similar order can be produced by random processes (Hiscott, 1981). There are no statistical procedures that will objectively identify and define the limits of upward thinning or thickening (upward fining or coarsening) sequences. Available tests will only establish (1) whether, on average, upward thinning trends are more common than upward thickening trends (Waldron, 1987), or (2) whether preselected sequences thin or thicken upward relative to symmetrical or random sequences of the same number of beds (Pickering et al., 1989, pp. 83-85). The latter procedure requires that the researcher first select a sequence of beds that are suspected to show an asymmetric trend of either bed thickness or grain size.
The FMS-based sedimentary logs (Figs. 4 and 5, back pocket) are continuous bed-by-bed sections that are ideal for investigation of trends in bed thickness. It is readily apparent that some parts of each $\log$ consist mainly of very thick beds (e.g., Fig. 4, back pocket, 2319 2417 mbrf; Fig. 5, back pocket, 4082-4105 and 4252-4326 mbrf). Visual inspection, however, reveals no consistent trends in bed thickness across the boundaries of, or within, these intervals. There are always thinner beds that disrupt any potential asymmetric sequences. At least one steplike upward thinning sequence occurs in Figure 4 (back pocket, 2312-2337 mbrf), but nongradational sequences of this type have a high probability of occurring through random processes (Pickering et al., 1989, p. 84).

Our impression is that the very thick beds in the Oligocene succession (Figs. 4 and 5, back pocket) are scattered more or less at random in a background of thinner beds. The only apparent internal organization is that very thick beds tend to cluster in some parts of each section; this is also true for parts of the succession not imaged with the FMS tool (Figs. 2 and 3). The impression of random occurrence of the very thick beds is strengthened by the resemblance of the succession of beds at Hole 792E to a random sequence containing the same number of beds (Fig. 15); the bed thicknesses in the random sequence have a power-law distribution with an exponent $b=1$. Without independent information, it is essentially impossible to distinguish between the actual succession of beds and the random sequence. Although very thick beds appear to cluster somewhat in the central part of the succession at Hole 792E (Fig. 4, back pocket), the same feature is present in the deeper part of the random sequence. The occurrence of clusters is, in fact, an inherent characteristic of sets of points separated by random intervals distributed according to a power law. These sets are commonly referred to as "random Cantor dusts" in the literature on fractals (Mandelbrot, 1983; Plotnick, 1986; Smalley et al., 1987).

In a geological context, of course, the clusters of very thick beds, often called "packets," must reflect local or regional changes in the volumes or pathways of sediment gravity flows. It is these changes that may occur randomly. Comparisons of the ages of the main coarse-grained packets at Sites 792 and 793 (Fig. 3) do not suggest that correlations exist. However, better biostratigraphic resolution is

\section{Hole 792E}
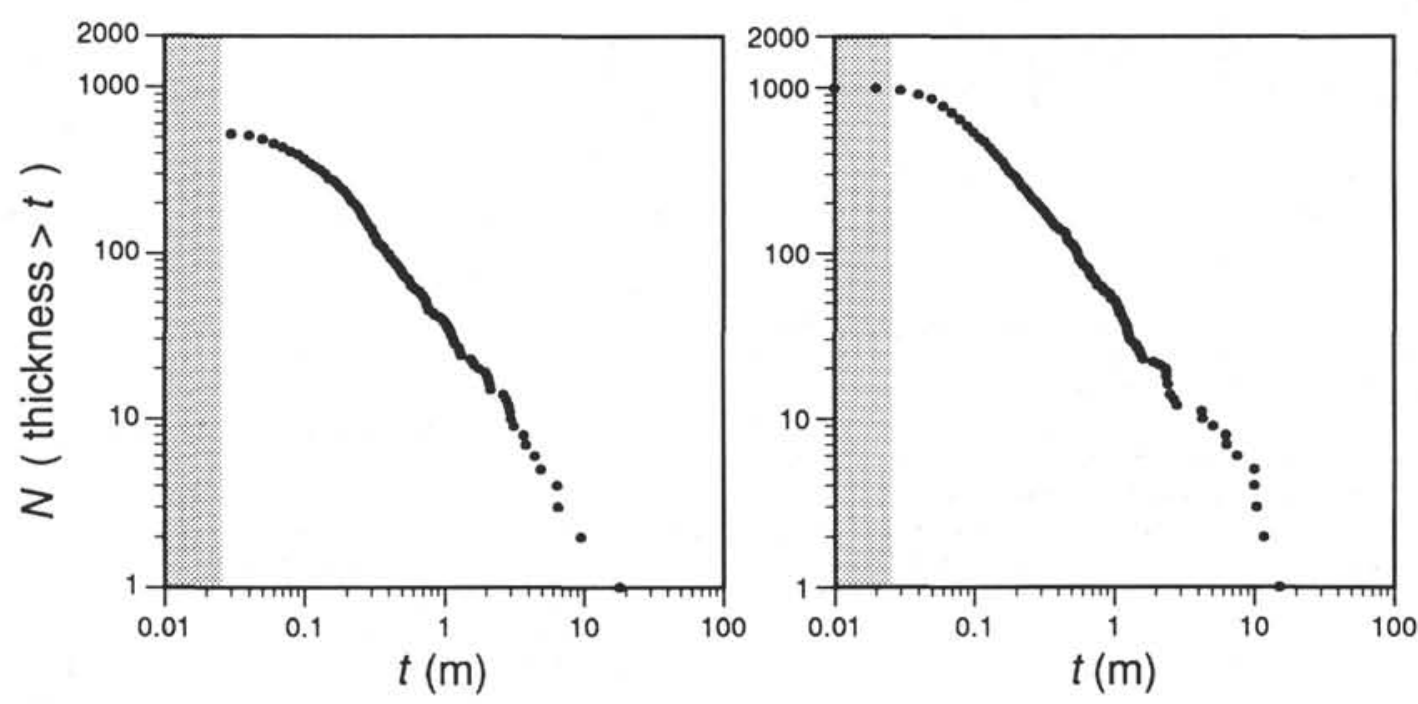

Figure 14. Logarithmic plot of the number of sandstone-shale couplets of thickness $>t$ vs. $t$ in the FMS-based sections. As predicted for a power-law distribution, the plot follows a straight line with a slope that is the characteristic exponent of the distribution (slightly $>1$ in this case). The stippled areas define the thickness interval below the resolution limit of the FMS tool (i.e., $2.5 \mathrm{~cm}$ ). 


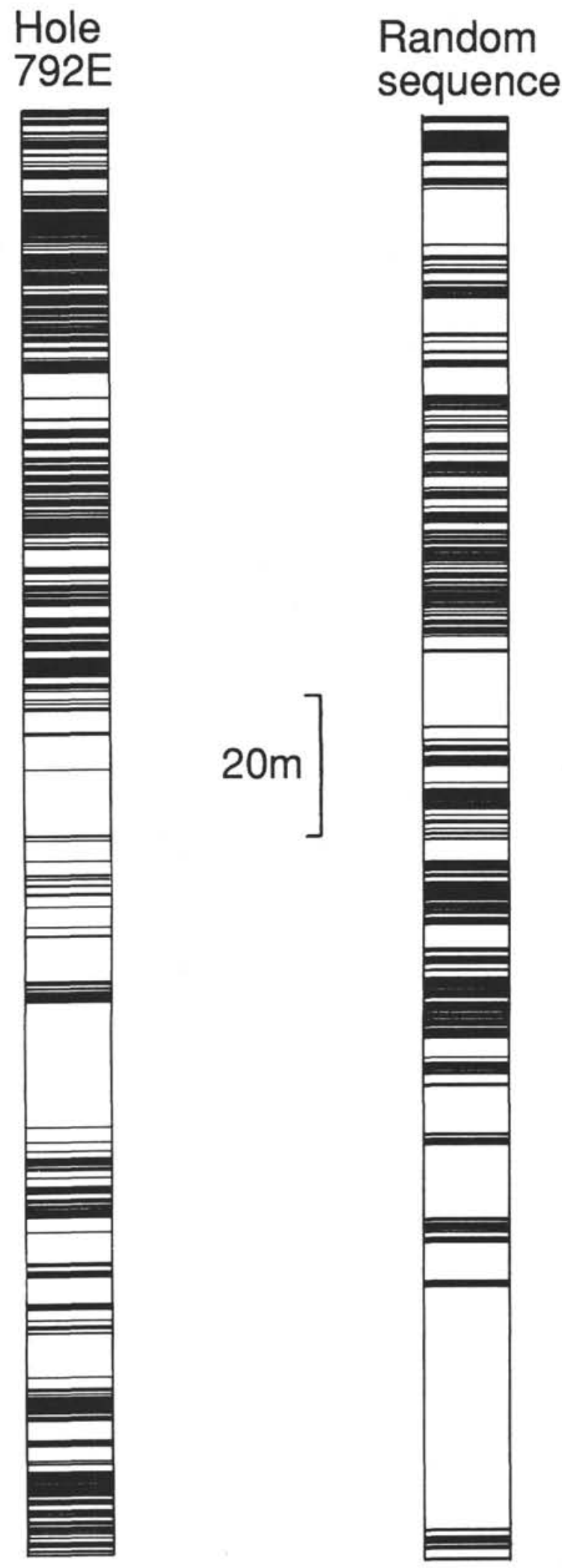

Figure 15. A plot of the bases of sandstone beds in the FMS-based log for Hole $792 \mathrm{E}$ compared with the plot of a random sequence. The random sequence contains the same number of bed boundaries, and the bed thicknesses are distributed according to a power law with a characteristic exponent of 1.0. necessary to completely rule out the existence, at times, of synchronous triggers for sand deposition throughout the forearc basin.

\section{Bed-thickness Frequencies and Recurrence Intervals for Sediment Gravity Flows}

The data files used to plot the FMS-based sedimentary logs were sorted to determine the number of sandstone beds in each bed-thickness class of Ingram (1954). The class for very thick beds was subdivided into the following thickness categories: $1-3,3-10$, and $>10 \mathrm{~m}$. The sedimentary log for Hole 793B (Fig. 5, back pocket) represents a time interval of about 1.15 m.y., with a relatively constant sedimentation rate. The log for Hole 792E (Fig. 4, back pocket) includes strata that were deposited at a decreasing rate: there is a slight decrease from 28.8 to $28.0 \mathrm{Ma}$, followed by a dramatic decrease from 28.0 to $26.0 \mathrm{Ma}$ that may be partly the result of loss of section here by faulting (Taylor, Fujioka, et al., 1990). For the purposes of a general assessment of average bed-thickness frequencies at Hole $792 \mathrm{E}$, we wish to avoid complications of nonstationary sedimentation rates. Hence, the extremely rapid decline (or removal of part of the section by faulting) after $28.0 \mathrm{Ma}$ is ignored, particularly as the bed thicknesses in this part of the section do not appear unusual. We, therefore, will only deal with the Hole 792E section that is deeper than 2257 mbrf (older than 28.0 $\mathrm{Ma}$ ) in the analysis that follows. The strata from 2257 to $2441 \mathrm{mbrf}$ were deposited in about 0.85 m.y.

Knowledge of the number of beds in each thickness class and the total time represented by each log permits calculation of the number of small to very large sediment gravity flows to reach each site per unit time (Table 1 and Fig. 16). Because the vertical resolution of the FMS tool is about $2.5 \mathrm{~cm}$, an unknown number of very thin beds may have been missed during examination of the images. At the other end of the spectrum, beds thicker than $10 \mathrm{~m}$ are so rare that recurrence intervals for the exceptional events that deposited them must have considerable uncertainty.

A derivative parameter is the recurrence interval for beds of different thicknesses (Table 1 and Fig. 17). As before, probable failure to recognize all very thin beds leads to artificially high recurrence intervals for these beds. For the other thickness classes, recurrence intervals range from about 4,000 to about $850,000 \mathrm{yr}$. The fact that the sandstone bed thicknesses are distributed according to a power law with a unit exponent implies that the recurrence interval is simply proportional to bed thickness. This prediction is illustrated by the

Table 1. Bed-thickness frequency data from FMS-based sedimentary logs, Holes 792E and 793B.

\begin{tabular}{|c|c|c|c|c|c|}
\hline Hole & $\begin{array}{l}\text { Depth } \\
\text { (mbrf) }\end{array}$ & $\begin{array}{l}\text { Thickness } \\
(\mathrm{cm})\end{array}$ & $\begin{array}{l}\text { Number of } \\
\text { beds }\end{array}$ & Number/m.y. & $\begin{array}{l}\text { Approximate } \\
\text { recurrence } \\
\text { interval }(\mathrm{yr})\end{array}$ \\
\hline $792 \mathrm{E}$ & $2232-2441$ & $\begin{array}{c}1-3 \\
3-10 \\
10-30 \\
30-100 \\
100-300 \\
300-1000 \\
>1000\end{array}$ & $\begin{array}{r}7 \\
133 \\
197 \\
83 \\
19 \\
7 \\
1\end{array}$ & \multicolumn{2}{|c|}{$\begin{array}{l}\text { Nonstationary because of } \\
\text { varying sedimentation rates }\end{array}$} \\
\hline $792 \mathrm{E}$ & $2257-2441$ & $\begin{array}{c}1-3 \\
3-10 \\
10-30 \\
30-100 \\
100-300 \\
300-1000 \\
>1000\end{array}$ & $\begin{array}{r}6 \\
104 \\
157 \\
61 \\
18 \\
7 \\
1\end{array}$ & $\begin{array}{c}7 \\
122 \\
185 \\
72 \\
21 \\
8.2 \\
1.2\end{array}$ & $\begin{array}{r}141,700 \\
8,170 \\
5,400 \\
13,900 \\
47,200 \\
121,400 \\
850,000\end{array}$ \\
\hline $793 B$ & $4023-4338$ & $\begin{array}{c}1-3 \\
3-10 \\
10-30 \\
30-100 \\
100-300 \\
300-1000 \\
>1000\end{array}$ & $\begin{array}{r}82 \\
325 \\
268 \\
93 \\
28 \\
7 \\
4\end{array}$ & $\begin{array}{c}71 \\
283 \\
233 \\
81 \\
24 \\
5 \\
3.5\end{array}$ & $\begin{array}{r}14,100 \\
3,500 \\
4,300 \\
12,400 \\
41,700 \\
200,000 \\
285,700\end{array}$ \\
\hline
\end{tabular}




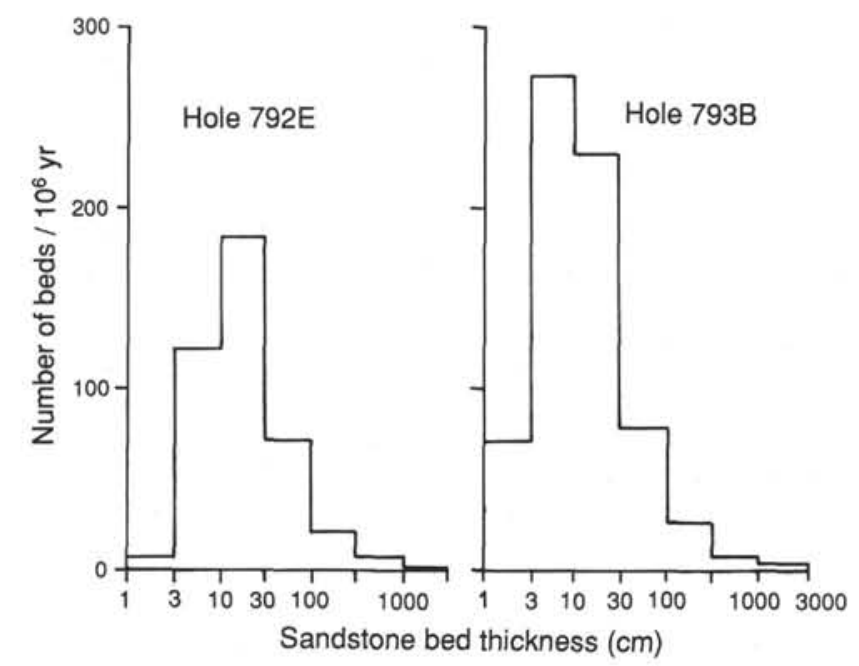

Figure 16. Histograms of sandstone and conglomerate bed thickness, normalized to a time interval of $1 \mathrm{~m} . \mathrm{y}$. Primary data were obtained from FMS images. The values for beds $1-3 \mathrm{~cm}$ thick are probably too low, because these beds are at or below the normal limit of resolution of the FMS tool.

dashed line of unit slope on Figure 17, paralleled by the data for sandstone bed thicknesses $\geq 10 \mathrm{~cm}$.

\section{Triggering Processes}

The turbidites and debris-flow deposits consist almost exclusively of volcaniclastic detritus derived by the failure of unconsolidated or semiconsolidated ejecta and epiclastic material that was situated around the active arc volcanoes. Possible triggers for sediment failures in this setting are (1) slope oversteepening because of increases in volcanic output (e.g., Moore et al., 1989), (2) seismic activity associated with major eruptions, (3) subduction-related earthquakes, and (4) longer term increased mobilization of material caused by falls in relative sea level (Mutti, 1985). Important proposed excursions in global sea level in the Oligocene are a drop of about $150 \mathrm{~m}$ at $30 \mathrm{Ma}$ and a rise of about $100 \mathrm{~m}$ at $25 \mathrm{Ma}$ (Haq et al., 1987). The rise at 25 Ma was probably accentuated by subsidence resulting from the initiation of rifting of the volcanic arc to form the Shikoku Basin (Hussong and Uyeda, 1981).

From a statistical point of view, one cannot objectively advocate different triggering mechanisms for thicker and thinner beds that belong to a single population distributed according to a power law (e.g., sea-level control for thinner beds and large earthquakes for very thick beds). This is because there is no objective way to separate the population into subsets of different bed thickness. If different processes are truly responsible for the generation of beds of different thickness, then the frequencies of these processes must scale exactly as needed to generate a population of bed thicknesses distributed according to a power law with a unique exponent. This seems a very unlikely coincidence.

Because the Leg 126 forearc sites are located above a subduction zone, we investigated, in a semiquantitative way, the potential of large-magnitude earthquakes as a triggering mechanism for very thick beds. An example of the potential for this type of analysis is provided by Kastens (1984), who related the frequency distribution of large earthquakes south of Italy with a time interval of about $1500 \mathrm{yr}$ between debris-flow deposits in cores from the Calabrian Ridge. The very thick beds in the Izu-Bonin forearc basin, however, have a much longer recurrence interval, which, for the purposes of this discussion, we consider to be about 300,000 yr (approximate upper range of values derived from multiple events in Table 1).

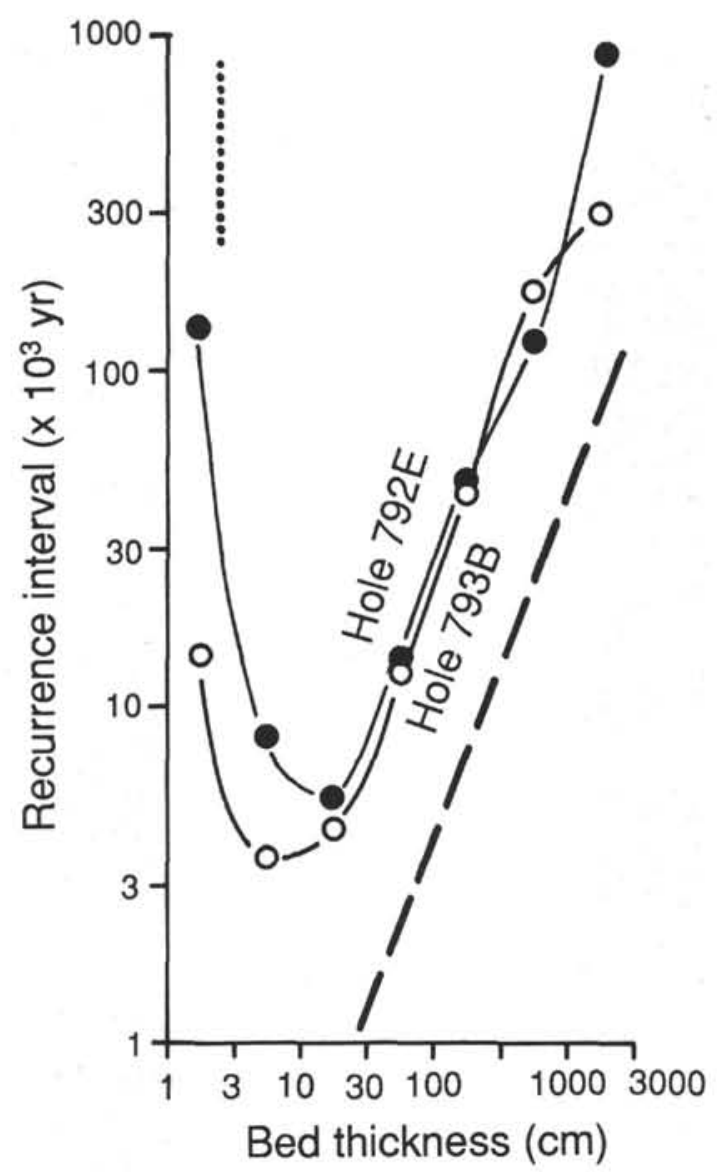

Figure 17. Recurrence intervals for beds of different thickness, derived from Figure 16. The values for beds $1-3 \mathrm{~cm}$ thick are probably too high, because these beds are at or below the normal limit of resolution of the FMS tool. The heavy dashed line has a slope that would indicate a recurrence interval proportional to bed thickness. Dotted line $=$ limit of FMS resolution.

To trigger the downslope movement of large volumes of sediment, earthquake shocks must be sufficiently strong to liquefy the material. According to Kuribayashi and Tatsuoka (1977) and Keefer (1984), only earthquakes with magnitudes greater than about 5.0 can cause significant liquefaction and, as distance from the epicenter increases, so does the minimum magnitude required for liquefaction. For example, a magnitude 7.0 shock can liquefy sediment as far as about 100 $\mathrm{km}$ from the epicenter, whereas distance increases to about $400 \mathrm{~km}$ for a magnitude 9.0 event.

Consider earthquakes of magnitude 7 or greater. Using historical records for the period 1905-1964, Duda (1965) determined a recurrence interval of $0.063 \mathrm{yr}$ ( 23 days) for the entire length of the circum-Pacific convergent margins, about $40,500 \mathrm{~km}$. For each 100 $\mathrm{km}$ segment of trench, therefore, the average recurrence interval is about $25 \mathrm{yr}$, in general agreement with more recent data around Japan (e.g., Mogi, 1990). Within each $100 \mathrm{~km}$ segment of the margin, earthquakes of magnitude 7 or greater should be capable of liquefying sediment to form sediment gravity flows (Keefer, 1984).

It appears that the recurrence interval of suitable seismic triggers in the vicinity of the Izu-Bonin forearc basin is 2 to 4 orders of magnitude less than the recurrence intervals for beds in all thickness classes (Table 1). However, there is an exponential decrease in the frequency of earthquakes as magnitude increases, so that the data used by Duda (1965) are strongly biased toward earthquakes near magnitude 7. Historical data on the frequency of very large earthquakes, of about magnitude 9, are not well constrained for the Izu-Bonin 
area. However, relationships developed by Faccioli (1977) and Kastens (1984) for other areas suggest that magnitude 9 events should occur about $1200 \times$ to $2000 \times$ less frequently than magnitude 7 events (using a focal distance of $400 \mathrm{~km}$ in the relationships), or about every $30,000-50,000 \mathrm{yr}$ for each $100 \mathrm{~km}$ length of the convergent margin. If such powerful tremors are needed to generate the largest sediment gravity flows at distances $<100 \mathrm{~km}$ from the site of the failure, then it becomes plausible that the frequency of deposition of the very thick beds is related to the frequency and proximity of very large earthquakes.

Clearly, factors other than availability of triggering events must be important in determining whether or not exceptionally large volumes of material can be mobilized. First, fresh volcanic materials, particularly glass shards, are very angular and probably require much higher ground accelerations (larger or closer earthquakes) to liquefy than would other siliciclastic materials. Second, the mean size of the material in the thicker beds is larger than medium sand: such material, unless it is mixed with fines, is not particularly susceptible to liquefaction (Andreson and Bjerrum, 1967). Finally, as emphasized by Piper et al. (1988) in their evaluation of the 1929 Grand Banks turbidity current, large flows depend on the availability of a suitable triggering mechanism and on the presence of large, unstable accumulations of loose material. In the case of the Izu-Bonin Arc, therefore, the very thickest beds may have only been generated when unusually large magnitude earthquakes occurred near (i.e., within perhaps 50 $100 \mathrm{~km}$ ) unusually large and unstable masses of volcaniclastic material, perhaps filling depressions on the flanks of volcanoes. At other times, smaller amounts of material were mobilized by smaller magnitude (or more distant) tremors, with the earthquake magnitudes, and therefore volumes of liberated material, obeying simple power-law distributions.

\section{PALEOCURRENTS}

\section{Methods and Limitations}

Two types of paleocurrent information were obtained, with critical orientations provided by the FMS images: (1) grain fabric in parallellaminated sandstone beds, and (2) ripple migration directions. Both types of data have fairly large sampling errors, but there are no other paleocurrent data for these Izu-Bonin forearc-basin deposits, and we think that the results are critical to an understanding of the sedimentology of these deposits.

Fourteen quarter-round samples were taken from parallel-laminated sandstones in dipping beds in Hole 792E. The length of each sample, along the core, was about $5 \mathrm{~cm}$. Bedding dips at these sample positions range from $5^{\circ}$ to $10^{\circ}$. Bedding dips in Hole 793B are much flatter, so that it was not possible to take samples in which the dip could be used to reorient the rock using FMS data.

Adipping plane will have different elevations around a cylindrical, vertical borehole. The two-dimensional representations used to display the FMS data (e.g., Fig. 18) are produced by splitting the data at the north position, and then unrolling and flattening the images from the cylindrical borehole onto a plane. When viewed in this way, an inclined bedding plane intersecting the borehole is defined by a sinusoid. Schlumberger software establishes a best fit sinusoid for the intersection of a plane and the borehole and then calculates the direction and amount of dip. This software was used to obtain dips at the depth of each fabric sample, after correction for the small deviations of the borehole from the vertical. Then, the samples were reoriented in the laboratory relative to the dip direction of the parallel lamination. This sample reorientation allows all grain fabric results to be expressed relative to true north.

Thin sections were first cut from the samples in the plane of the parallel lamination. The dip direction was recorded on each thin section as a reference line. Thin sections were projected onto a sheet of tracing paper on the screen of a Shadowmaster microprojector, at magnifications of $50 \times$ or $100 \times$. Only pyroxene or feldspar crystals with short-to-long-axis ratios of $<0.7$ were outlined on the tracing paper, and then only if the grain was located at an intersection point of a square grid (about $2.5-\mathrm{cm}$ spacing) superimposed on the microprojector screen. All clearly visible sand grains, regardless of their size, were included in this analysis. The thin section was translated as necessary on the Shadowmaster stage until 100 grains had been outlined. Later, lines were drawn through each outlined grain, according to the "least projection elongation" criterion of Dapples and Rominger (1945; see sketch in Hiscott and Middleton, 1980), unless the grain displayed bilateral symmetry in its longest dimension, in which case the trace of the symmetry plane was chosen. The orientations of the lines were measured with reference to the dip direction and grouped into $10^{\circ}$ classes from $0^{\circ}$ to $180^{\circ}$. These data were evaluated for preferred orientation with the Tukey $\chi^{2}$ test (Harrison, 1957; Middleton, 1965), and vector magnitudes were calculated (Curray, 1956).

Six samples with $\chi^{2}$ significance levels $<0.20$ were selected for imbrication measurement. Three of these are in the depth range of the FMS-based sedimentary log (Fig. 4, back pocket), and three are below this level. From the remaining piece of core, a second thin section was cut perpendicular to the lamination and in the direction of the preferred orientation. Measurement of the grain imbrication in these samples, relative to the lamination, allowed unambiguous selection of the paleoflow direction for three samples.

Because the bedding dips are quite shallow, transfer of the dip direction to the first thin section is probably only accurate to $\pm 15^{\circ}$. Vector magnitudes for samples that passed the Tukey $\chi^{2}$ test range from $14.78 \%$ to $23.73 \%$, corresponding to $95 \%$ confidence limits about the computed vector mean of about $\pm 8^{\circ}-9^{\circ}$ (Curray, 1956, fig. 3 ). Therefore, computed vector means (see below) should only be assumed to be accurate to within $20^{\circ}$ to $25^{\circ}$ of the true grain orientation in the rock. Imbrication measurements have less error because the reference line in the sample is the plane of the lamination, which is clearly defined in the thin sections. All but one of the imbrication fabrics have $95 \%$ confidence limits about the computed vector mean of about $\pm 6^{\circ}-7^{\circ}$. To guard against the incorrect specification of flow direction, however, only mean imbrication angles of $\geq 10^{\circ}$ relative to the lamination were used to select the direction of paleoflow from the two possibilities given by the long-axis elongation.

Ripple-scale cross lamination is visible in the FMS images of many turbidite beds. This cross lamination is more subtle than parallel lamination, and can only be appreciated and measured, with confidence, on the screen of the Schlumberger workstation. An example of the appearance of the cross lamination, with interpretation, is given in Figure 18. In the four FMS image strips, each mapping about 7\% of the borehole wall, cross lamination generally is intersected at some unknown angle from the direction of maximum foreset dip, giving an apparent dip only. A complicating factor is that ripple-scale cross lamination generally consists of troughs, so that the direction of maximum foreset dip at any point may not be parallel to the paleoflow direction. We cannot compensate for this or other geometric irregularities of ripples in our analysis of the FMS images and, therefore, are compelled to assume parallel foresets unless there is evidence to the contrary.

During our examination of the color-enhanced images at the Schlumberger workstation, we identified 21 possible examples of cross lamination in the Hole $792 \mathrm{E}$ images, and 34 possible examples in the Hole 793B images. Because of the variable image quality and low resistivity contrasts, the cross lamination was not generally visible in all four image strips. Where visible, a sinusoid was fitted to the dipping lamination in the record from one pad of the tool and forced through the same stratigraphic level in the record from the pad on the opposite side of the borehole, thus defining a plane with a dip parallel to the apparent dip of the cross lamination on the wall of the borehole. If possible, this procedure was repeated for the same ripple train using apparent dips from cross lamination visible in other image strips, preferably at $90^{\circ}$ from the first. The planes defined by these 


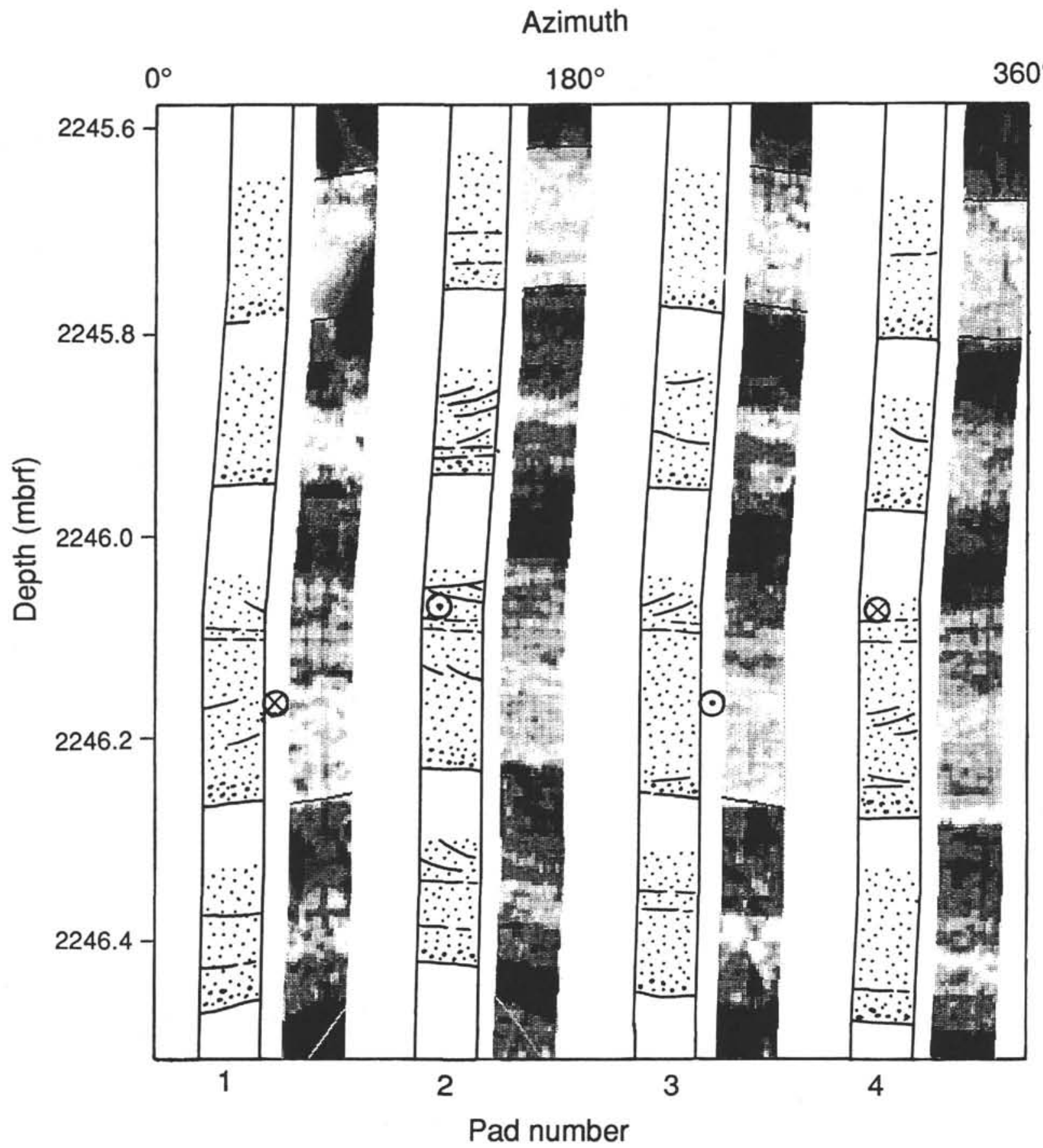

Figure 18. Interpretation of FMS images through beds with apparent cross lamination, Hole 792E. The sketches are correctly positioned relative to compass directions, whereas the FMS images are not. The elevation of the bases of the beds differs from pad to pad because the beds are dipping to the northwest. Apparent cross lamination in the bed at 2245.8-2245.95 mbrf is, in fact, much steeper than the angle of repose. Acceptable results were obtained from two levels in the underlying, probably composite bed (Table 3); circled dots and circled crosses represent, respectively, the heads and tails of arrows aligned with the inferred ripple migration directions. For reasons given in the text, the quality of these images is much poorer than that available at the Schlumberger workstation.

apparent dips were plotted on a Schmidt stereonet, corrected for local bedding dip, and the true dip and orientation of the foreset plane were determined; this plane, by definition, contains both apparent-dip lines. If only one apparent dip could be determined, generally with replication on a second lamina in the same image strip, then it was corrected for bedding dip on the Schmidt net and used as outlined below.

The angle of repose of sand after avalanching down the lee face of a bedform ranges from $30^{\circ}$ to $35^{\circ}$ (Allen, 1982, pp. 61-62). As a result of (1) the generally festoon shape of ripple foresets and (2) postdepositional compaction, most foresets in fine-grained sandstone have a lesser slope with a maximum value that we estimate to be about $25^{\circ}$. The ripple results obtained from stereonet analysis were given numerical rankings from 1 (trustworthy) to 3 (unreliable), based on criteria that are the same for foreset dips defined either by one or by more than one apparent dip. The rank depends mainly on the amount of foreset dip: dip $20^{\circ}-30^{\circ}=\operatorname{Rank} 1$; dip $15^{\circ}-20^{\circ}$ or $30^{\circ}-35^{\circ}=$ Rank 
2 ; and lower or higher dips $=$ Rank 3 . A few ranks that deviate from these criteria do so because of some uncertainty as to whether the dipping feature on the FMS images truly represents cross lamination and not some other structure (e.g., a fracture) or an artifact of the data acquisition or processing. The number of foreset orientations for each numerical rank, followed in brackets by the number of orientations that were determined using more than one apparent dip, are as follows: Rank 1, 25 (15); Rank 2, 16 (11); and Rank 3, 14 (13).

The accuracy of individual foreset dip directions is fairly poor, mainly because of our lack of ability to account for complex foreset shapes. For foresets defined by more than one apparent dip, the result may be within about $\pm 25^{\circ}$ of the true migration direction of the ripples. For foresets assumed to be orthogonal to fairly steep apparent dips (single determinations), the true migration direction could be anywhere within about $\pm 40^{\circ}$ of the reported value (Fig. 19).

Even if measurement errors could be accounted for, paleocurrents obtained from the upper parts of turbidites are known to show more scatter than data from sole markings and basal grain fabric, mainly because the decelerating tails of the currents meander (Parkash and Middleton, 1970). This factor contributes additional uncertainty to the usefulness of the ripple migration directions in specifying dispersal patterns in the basin.

\section{Grain Fabric Data}

Results of the fabric measurements for the six samples that have preferred long-axis orientations (Tukey $\chi^{2}$ significance level $<0.20$ ) are given in Table 2 . The three samples for which only line-of-motion could be determined all have imbrication angles that could not be distinguished from zero. Nevertheless, the combined data from Hole $792 \mathrm{E}$ give an impression of consistent paleoflow toward the southeast (mean $=148^{\circ}$; Fig. 20 ), slightly to the east of the axis of the forearc basin. Data within the depth range of the FMS-based sedimentary log (Fig. 4, back pocket) are plotted adjacent to the sample position.

\section{Ripple Orientations}

The inferred ripple migration directions of Ranks 1 and 2 are presented in Table 3 and are plotted on the FMS-based sedimentary logs (Figs. 4 and 5, back pocket). Rose diagrams (Fig. 21) graphically show the wide scatter of the data. For the older and more basinward section at Site 793, deposited from 30.2 to $29.5 \mathrm{Ma}$, there is a gap in the data from $15^{\circ}$ to $117^{\circ}$ that could be interpreted to point upcurrent to a northeasterly source. However, the general scatter in the data and the fact that more reliable grain-fabric data, albeit in younger rocks deposited from 28.9 to $27.3 \mathrm{Ma}$, indicate a northwesterly source cause us to refrain from drawing any firm conclusions about provenance based on the ripple orientations.

Some of the scatter is certainly a result of errors associated with trying to measure the true migration directions of the ripples in the FMS images. A large part of the scatter, however, is probably real and indicates that the more dilute tails of turbidity currents were relatively free to move in a variety of directions across the floor of the basin.

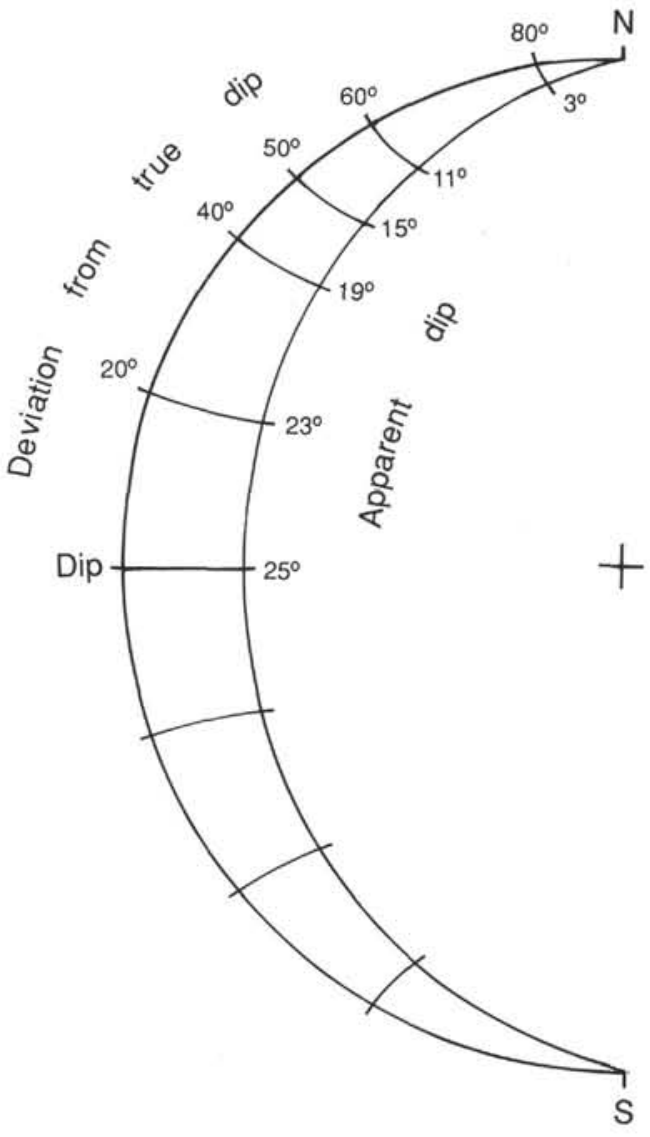

Figure 19. Margin of a Schmidt stereonet, and position of the great circle for a plane dipping at $25^{\circ}$, the approximate angle of repose of fine sand under water. In a direction $45^{\circ}$ away from the true dip direction, the apparent dip is still quite large, about $17^{\circ}$.

This is consistent with a rather featureless basin-plain setting, supported by the lack of major channels in seismic data (Taylor et al., 1990; Klaus and Taylor, 1991).

\section{OLIGOCENE BASIN EVOLUTION}

The oldest deposits drilled by Leg 126 (about $30.5 \mathrm{Ma}$ ) consist predominantly of very thick beds of coarse-grained sandstone, pebbly sandstone, and fine-pebble conglomerate. At Site 793, where there is a more complete record (there is an unconformity at about $715 \mathrm{mbsf}$ in the section at Site 792), pebbles were partly derived by erosion of (1) a volcanic terrane, including basalts to rhyolites (Taylor, Fujioka, et al., 1990), and (2) a shallow-marine shelf colonized by large foraminifers and calcareous algae (Nishimura, this volume). At least

Table 2. Grain fabric data, Hole 792E.

\begin{tabular}{|c|c|c|c|c|c|c|}
\hline \multirow[b]{2}{*}{$\begin{array}{l}\text { Core, section, } \\
\text { interval }(\mathrm{cm})\end{array}$} & \multirow[b]{2}{*}{$\begin{array}{l}\text { Depth } \\
\text { (mbrf) }\end{array}$} & \multicolumn{2}{|c|}{ Long-axis } & \multicolumn{2}{|c|}{ Imbrication } & \multirow[b]{2}{*}{$\begin{array}{r}\text { Paleoflow } \\
\text { (degrees) }\end{array}$} \\
\hline & & $\begin{array}{c}\text { Trend } \\
\text { (degrees) }\end{array}$ & $\begin{array}{c}\text { Vector } \\
\text { magnitude }(\%)\end{array}$ & $\begin{array}{c}\text { Angle } \\
\text { (degrees) }\end{array}$ & $\begin{array}{c}\text { Vector } \\
\text { magnitude }(\%)\end{array}$ & \\
\hline \multicolumn{7}{|l|}{$126-792 \mathrm{E}-$} \\
\hline $48 R-3,7-12$ & 2389.2 & $18-198$ & 14.85 & 10 & 45.33 & 198 \\
\hline $48 R-5,75-80$ & 2392.5 & $131-311$ & 14.74 & 5 & 26.61 & - \\
\hline 50R-3, 34-38 & 2408.9 & $127-307$ & 23.73 & 1 & 13.70 & - \\
\hline $55 \mathrm{R}-2,80-83$ & 2456.2 & $163-343$ & 17.96 & 2 & 38.64 & - \\
\hline 57R-5, 74-79 & 2480.0 & $104-284$ & 15.98 & 11 & 47.15 & 104 \\
\hline $59 R-4,80-85$ & 2497.5 & $163-343$ & 15.78 & 15 & 30.60 & 163 \\
\hline
\end{tabular}

Note: mbrf $=$ meters below rig floor. 


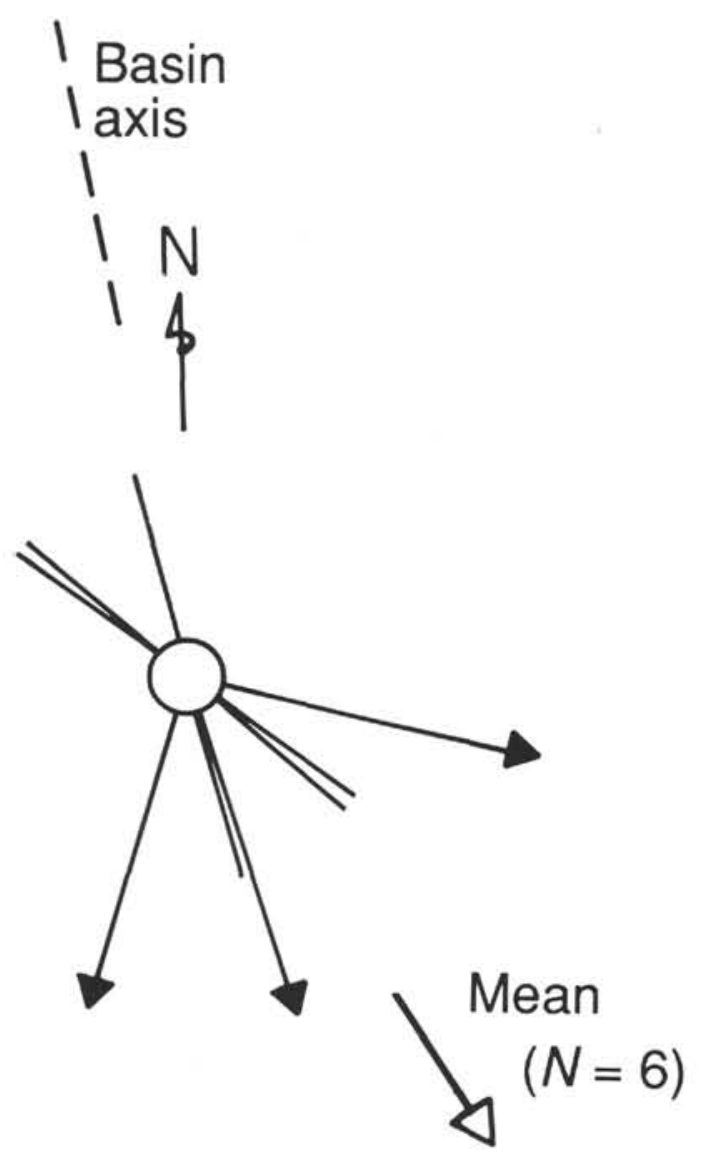

Figure 20. Grain fabric results in Hole 792E (Table 2), plotted relative to true north and the trend of the axis of the forearc basin (Fig. 1B). Imbrication measurements are successful in determining flow direction for the three results plotted with solid arrow heads. Other long-axis measurements, plotted on both sides of the origin, only give line-of-motion information. The mean of all six fabric determinations, assuming the south-southeast quadrant to include the downcurrent direction, is $148^{\circ}$ (arrow with open head).

some of the fossil material is older than the forearc-basin succession (middle to upper Eocene foraminifers in upper Oligocene sediment gravity flows; Matsumaru et al., this volume). Many of the large foraminifers, however, are single unabraded tests that were probably derived from unconsolidated shelf materials. These exist in cored material to a depth of about 4150 mbrf. The ranges of most of the foraminifer species are so long that it is impossible to say if they were resedimented into the basin while alive, soon after death, or hundreds of thousands of years after death (Matsumaru et al., this volume).

The concentration of coarse, pebbly beds in strata deposited at about $30.5 \mathrm{Ma}$, and the inclusion of bioclastic debris in these and overlying sandstones until about $30.0 \mathrm{Ma}$ (Fig. 3), may be a reflection of the proposed major drop in sea level at $30 \mathrm{Ma}$ (Haq et al., 1987). This lowering of base level around the volcanoes would have made available large amounts of unconsolidated debris, including erosional products from older rocks, and bioclasts from shelf deposits (e.g., carbonates on the Bonin Islands; Hanzawa, 1947) that became exposed either to subaerial erosion or to the increased action of waves in shallower water. A major drop in sea level may have also promoted increased volcanic activity as a result of the unloading and depressurizing of the arc volcano flanks (cf. Wallmann et al., 1988). An additional factor may have been the tectonic movements associated with the extension that produced the forearc basin (Taylor, this volume). Uplifting of the rift flanks, deepening of the basin, steepening of the
Table 3. Formation microscanner ripple foreset dips and numerical rankings, Holes 792E and 793B.

\begin{tabular}{ccccc}
\hline $\begin{array}{c}\text { Depth } \\
\text { (mbrf) }\end{array}$ & $\begin{array}{c}\text { Dip } \\
\text { (degrees) }\end{array}$ & $\begin{array}{r}\text { Paleoflow } \\
\text { (degrees) }\end{array}$ & Rank & $\begin{array}{c}\text { Number of } \\
\text { apparent dips }\end{array}$ \\
\hline 126-792E- & & & & \\
2241.20 & 30 & 278 & 2 & 2 \\
2246.10 & 31 & 118 & 1 & 1 \\
2246.20 & 28 & 228 & 1 & 1 \\
2247.40 & 25 & 220 & 1 & 1 \\
2247.65 & 31 & 55 & 1 & 2 \\
2253.50 & 28 & 74 & 2 & 2 \\
2255.40 & 30 & 64 & 1 & 2 \\
2260.40 & 26 & 160 & 1 & 3 \\
2299.20 & 20 & 202 & 1 & 1 \\
2300.30 & 35 & 160 & 2 & 2 \\
2343.00 & 25 & 315 & 1 & 1 \\
2385.10 & 24 & 66 & 1 & 2 \\
2392.50 & 24 & 16 & 1 & 1 \\
2425.40 & 27 & 57 & 1 & 2 \\
2431.40 & 17 & 258 & 2 & 2 \\
2472.70 & 28 & 336 & 2 & 3 \\
$126-793 B-$ & & & & \\
4024.95 & 17 & 244 & 2 & 2 \\
4025.05 & 24 & 338 & 1 & 2 \\
4049.80 & 19 & 239 & 2 & 1 \\
4059.10 & 16 & 275 & 2 & 2 \\
4064.80 & 25 & 280 & 1 & 1 \\
4074.20 & 18 & 293 & 2 & 1 \\
4098.60 & 17 & 165 & 2 & 1 \\
4105.80 & 22 & 15 & 1 & 1 \\
4111.20 & 19 & 255 & 2 & 1 \\
4113.80 & 22 & 140 & 1 & 2 \\
4117.00 & 19 & 168 & 2 & 1 \\
4124.20 & 20 & 301 & 1 & 2 \\
4126.60 & 33 & 118 & 2 & 2 \\
4144.90 & 21 & 334 & 1 & 2 \\
4145.90 & 27 & 228 & 1 & 2 \\
4146.10 & 22 & 175 & 2 & 3 \\
4148.60 & 20 & 242 & 1 & 1 \\
4185.30 & 22 & 237 & 1 & 2 \\
4192.30 & 26 & 207 & 1 & 2 \\
4194.90 & 22 & 235 & 1 & 2 \\
4202.10 & 28 & 117 & 1 & 2 \\
4232.40 & 22 & 6 & 1 & 2 \\
4234.00 & 20 & 22 & 1 & 2 \\
4241.20 & 16 & 204 & 2 & 2 \\
4243.60 & 17 & 157 & 2 & \\
\hline
\end{tabular}

Note: $\mathrm{mbrf}=$ meters below rig floor.

bottom slopes, increased seismic activity, and perhaps augmented volcanicity would have all contributed to the coarse-grained and very thickly bedded interval at the base of the unit. In this scenario, the subsequent upward fining above about $1280 \mathrm{mbsf}$ at Site 793 (about 4250 mbrf, Fig. 5 , back pocket) may have been produced by a combination of effects: a decreasing rate of extension; a decline in the elevation and extent of the source area; and a decrease in seafloor gradients along the basin-margin slopes because of basin infilling.

Depositional rates at Site 793 remained fairly constant until about 29.0 Ma (Fig. 3), and sedimentation was characterized by mixed thinand thick-bedded, basin-plain turbidites, punctuated periodically by deposition from large-volume, high-concentration turbidity currents and debris flows. At about $29 \mathrm{Ma}$, deposition was renewed above the unconformity at Site 792 , and from then until about 28.0 Ma the rate of accumulation at this site exceeded that at Site 793. Grain-fabric data from medium- to coarse-grained sandstones indicate predominantly axial transport from north to south, with a small component of flow away from the western margin of the basin.

Other local and regional data suggest that the principal latest Oligocene source area was to the west, consistent with the grain-fabric results. At Site 787, depositional rates are lower, and $\mathrm{CaCO}_{3}$ contents in mudstones higher, than at Site 792 to the west. This cannot be attributed to a shallower depositional setting for Site 787 than for Site 792 (e.g., on a basin-margin slope) because benthic foraminifers at both sites indicate similar depths of about 3-4 km in the late Oligocene (Taylor, Fujioka, et al., 1990). Further west, at DSDP Site 296 on the Palau-Kyushu Ridge, which in the Oligocene formed part of the western margin of the forearc basin, equivalent upper Oligocene rocks are tuffs, lapilli tuffs, and volcanic sandstones and siltstones of more proximal character than the Leg 126 successions (Karig, Ingle, et al., 1975). In a west-east transect from the Palau-Kyushu Ridge to Site 


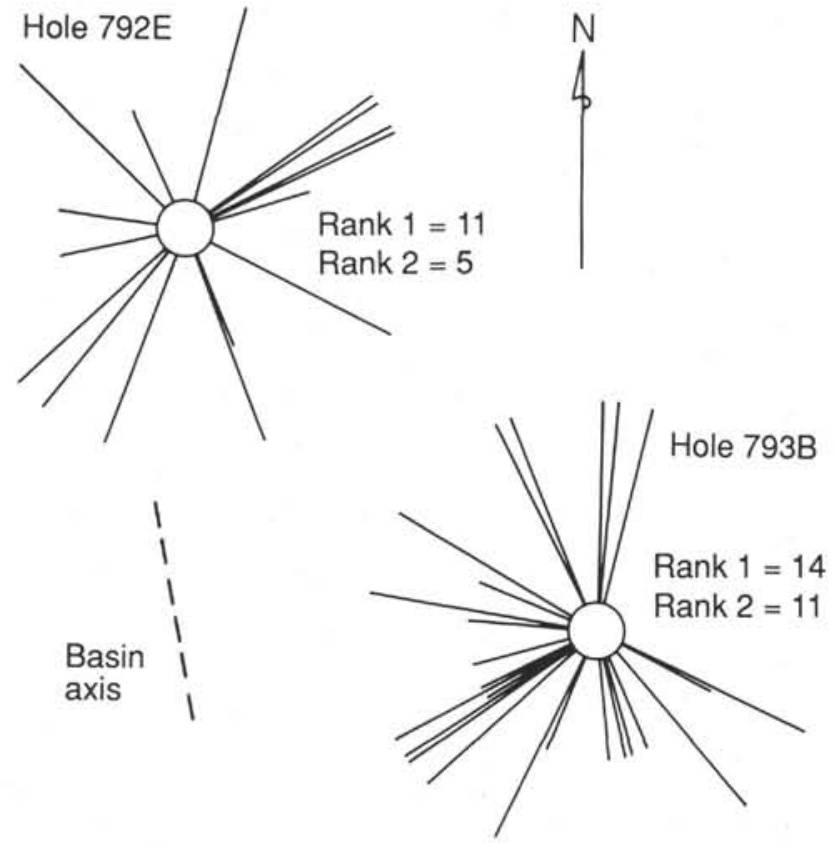

Figure 21. Rose diagrams summarizing ripple-migration directions deduced from FMS images in Holes 792E and 793B. The data are plotted relative to true north and the trend of the axis of the forearc basin (Fig. 1B). Each estimate is plotted as a line that points in the direction of paleoflow. The lines for Rank 1 data are twice as long as the lines for Rank 2 data.

787 , therefore, there is a consistent decrease in proximal character and coarseness of the uppermost Oligocene deposits, indicating that the main sediment source at this time probably lay to the west.

The strong component of paleoflow from north to south along the axis of the basin (i.e., grain-fabric results; Fig. 20) is consistent with the general thickening of the entire Oligocene section from the vicinity of the Leg 126 forearc sites toward the more southerly Bonin Trough (Taylor et al., 1990). The north to south tilt of the basin axis that we speculate controlled the paleoflow at about $29.0 \mathrm{Ma}$ seems, on a regional scale, to have persisted to the present day.

There is a concentration at Sites 792 and 793 of very thick beds of coarse-grained sandstone, pebbly sandstone, and minor conglomerate with approximate ages from 28.8 to $27.8 \mathrm{Ma}$ (Figs. 2 and 3). There are proposed fluctuations in global sea level of about $50 \mathrm{~m}$ in this time interval (Haq et al., 1987) that may account for fluctuations in the grain size and thickness of beds, following the arguments of Mutti (1985). This explanation for sandbody deposition would require, however, that "packets" of coarser beds have the same age at different sites around the basin. Because there is no firm evidence that individual sandbodies in the main basin fill correlate from site to site, it is more likely that local coarse-grained packets reflect really restricted increases in either source-area elevation (i.e., tectonic uplift), or intensity of volcanism, or both.

The last important stage in the evolution of the forearc basin is the sharp decline in sedimentation rates and increase in the abundance of mudstones and nannofossil-rich lithologies in the time period from 27 to $23.5 \mathrm{Ma}$. This fine-grained blanket effectively completed filling of the basin to the level of the outer-arc high on its eastern side. Two factors may account for this change in style of sedimentation. First, there is a proposed rise in global sea level of about $100 \mathrm{~m}$ at $25 \mathrm{Ma}$ (Haq et al., 1987) that would have drowned subaerial parts of the volcanic chain and increased water depths above other parts, placing them below the effects of wave action. This would have sharply reduced the supply of volcaniclastic detritus and allowed accumulation of nannofossil-rich mudstones. Second, the Shikoku Basin began to open at about $25 \mathrm{Ma}$ (Kobayashi and Nakada, 1979), splitting the active arc in two. This may have been responsible for a reduction in volcanic output (Hussong and Uyeda, 1981) and subsidence of the arc volcanoes. Such subsidence would have been equivalent in effect to a global rise in sea level.

\section{CONCLUSIONS}

Formation microscanner images, obtained for the first time by ODP on Leg 126, permit construction of complete bed-by-bed sections through major parts of the Oligocene turbidite succession in the Izu-Bonin forearc basin. Bed thicknesses in the forearc turbidite succession are distributed according to a power law with an exponent of about 1.0. Because all beds belong to the same distribution, we hesitate to propose different triggering mechanisms for flows of different scales.

The vertical distribution of beds with different thickness is essentially random; there are few, if any, clear examples of upward thinning or thickening sequences. Spaced packets of thick and very thick beds may be a response to low stands of global sea level, particularly at 30 Ma. Lack of channels, lack of cyclicity, and variable paleocurrents, particularly ripple migration data, all point to a basin-plain setting for the Oligocene succession.

Grain-fabric data for the period from 28.9 to 27.3 Ma suggest predominantly axial transport from north to south, with a small component of flow away from the western margin of the basin. Regional considerations suggest that the major source of detritus at this time was along the western basin margin. The axial gradient that characterized the forearc basin at this time has persisted in a general way to the present, accounting for the general thickening of the basin fill from the area of the Leg 126 forearc sites to the Bonin Trough.

Earthquakes are a probable triggering mechanism for sediment gravity flows in the forearc basin. The recurrence intervals for earthquakes capable of causing liquefaction of sands are much shorter than the recurrence intervals for sandstone beds $>10 \mathrm{~m}$ thick, which are on the order of $300,000 \mathrm{yr}$. Instead, the very thickest beds may have been generated by very large earthquakes (about magnitude 9) that occurred close to large, unstable accumulations of volcaniclastic sand or ash on the flanks of arc volcanoes.

We speculate that the sharp decline in sedimentation rates and increase in the abundance of mudstones and nannofossil-rich lithologies, in the time period from 27 to $23.5 \mathrm{Ma}$, may be the result of a proposed rise in global sea level of about $100 \mathrm{~m}$ at $25 \mathrm{Ma}$, coupled with subsidence of the arc volcanoes as a result of synrift extension and subsequent spreading in the Shikoku Basin.

\section{ACKNOWLEDGMENTS}

Without the energetic efforts of Roger Anderson, Borehole Research Group of Lamont-Doherty Geological Observatory, the formation microscanner would probably not have been available and operational for Leg 126 . We heartily thank him for making this research possible. Robin Reynolds of Lamont-Doherty is thanked for making special efforts to provide Hiscott with high-quality copies of first-run FMS images. Technical staff at Memorial University were critical to completion of the laboratory work: Helen Gillespie entered all FMS-based depths and grain sizes into a computer data base and performed the grain-fabric measurements; and David MacNeil prepared, with several iterations, the AutoCad drawings of the FMSbased sedimentary sections. Measurement of ripple orientations and bedding could only be performed on a Schlumberger workstation; Sal Gallegos, Schlumberger (Dallas, Texas), generously provided inexpensive workstation time and personal assistance outside of normal working hours, for which we are particularly thankful.

\section{REFERENCES}

Allen, J.R.L., 1982. Sedimentary Structures: Their Character and Physical Basis (Vol. 1): Amsterdam (Elsevier). 
Andresen, A., and Bjerrum, L., 1967. Slides in subaqueous slopes in loose sand and silt. In Richards, A. F. (Ed.), Marine Geotechnique: Urbana (Univ. Illinois Press), 221-239.

Bouma, A. H., 1962. Sedimentology of Some Flysch Deposits: Amsterdam (Elsevier).

Bourke, L., Delfiner, P., Fett, T., Grace, M., Lüthi, S., Serra, O., and Standen, E., 1989. Using Formation MicroScanner images. Tech. Rev. (Schlumberger), 37:16-40.

Curray, J. R., 1956. Analysis of two-dimensional orientation data. J. Geol., 64:117-131.

Dapples, E. C., and Rominger, J. F., 1945. Orientation analysis of fine-grained clastic sediments. J. Geol., 53:246-261.

Duda, S. J., 1965. Secular seismic energy release in the circum-Pacific belt. Tectonophysics, 2:409-452.

Faccioli, E., 1977. Site dependent probability distributions for peak ground motion parameters in strong earthquakes. Inst. de Ingenieria, U.N.A.M. (Mexico), Report E23.

Fryer, P., Pearce, J. A., Stokking, L. B., et al., 1990. Proc. ODP, Init. Repts., 125: College Station, TX (Ocean Drilling Program).

Hanzawa, S., 1947. Eocene foraminifera from Hahajima. J. Paleontol., 21:254-259.

Haq, B. U., Hardenbol, J., and Vail, P. R., 1987. Chronology of fluctuating sea levels since the Triassic. Science, 235:1156-1167.

Harrison, P. W., 1957. New technique for three-dimensional fabric analysis of till and englacial debris containing particles from 3 to 40 millimetres in size. J. Geol., 65:98-105.

Hiscott, R. N., 1981. Deep-sea fan deposits in the Macigno Formation (middle-upper Oligocene) of the Gordana Valley, northern Apennines, Italydiscussion. J. Sediment. Petrol., 51:1015-1021.

Hiscott, R. N., and Middleton, G. V., 1979. Depositional mechanics of thickbedded sandstones at the base of a submarine slope, Tourelle Formation (Lower Ordovician), Quebec, Canada. In Doyle, L. J., and Pilkey, O. H. (Eds.), Geology of Continental Slopes. Spec. Publ.-Soc. Econ. Paleontol. Mineral., 27:307-326.

1980. Fabric of coarse deep-water sandstones, Tourelle Formation, Quebec, Canada. J. Sediment. Petrol., 50:703-722.

Hiscott, R. N., Pickering, K. T., and Beeden, D. R., 1986. Progressive filling of a confined Middle Ordovician foreland basin associated with the Taconic Orogeny, Quebec, Canada. In Allen, P. A., and Homewood, P. (Eds.), Foreland Basins. Spec. Publ., Internat. Assoc. Sedimentol., 8:309-325.

Honza, E., and Tamaki, K., 1985. The Bonin Arc. In Nairn, A.E.M., Stehli, F. G., and Uyeda, S. (Eds.), The Ocean Basins and Margins (Vol. 7): New York (Plenum), 459-502.

Hsü, K. J., 1983. Actualistic catastrophism: address of the retiring President of the International Association of Sedimentologists. Sedimentology, 30:3-9.

Hussong, D. M., and Uyeda, S., 1981. Tectonic processes and the history of the Mariana Arc: a synthesis of the results of Deep Sea Drilling Project Leg 60. In Hussong, D. M., Uyeda, S., et al., Init. Repts. DSDP, 60: Washington (U.S. Govt. Printing Office), 909-929.

Ingram, R. L., 1954. Terminology for the thickness of stratification units and parting units in sedimentary rocks. Geol. Soc. Am. Bull., 65:937-938.

Karig, D. E., Ingle, J. C., Jr., et al., 1975. Init. Repts. DSDP, 31: Washington (U.S. Govt. Printing Office)

Kastens, K. A., 1984. Earthquakes as a triggering mechanism for debris flows and turbidites on the Calabrian Ridge. Mar. Geol., 55:13-33.

Keefer, D. K., 1984. Landslides caused by earthquakes. Geol. Soc. Am. Bull., 95:406-421.

Klaus, A., and Taylor, B., 1991. Submarine canyon development in the Izu-Bonin forearc: a SeaMARC II and seismic survey of Aoga Shima canyon. Mar. Geophys. Res., 13:131-152.

Kobayashi, K., and Nakada, M., 1979. Magnetic anomalies and tectonic evolution of the Shikoku inter-arc basin. In Uyeda, S., Murphy, R., and Kobayashi, K. (Eds.), Geodynamics of the Western Pacific: Advances Earth Planet Sci. Ser, Tokyo (Japanese Sci. Soc. Press), 6:391-402.

Kuribayashi, E., and Tatsuoka, F., 1977. History of earthquake-induced soil liquefaction in Japan. Bull. Public Works Res. Inst. (Jpn. Min. Construction), 31:1-26.

Kuroda, N., and Shiraki, K., 1975. Boninite and related rocks of Chichi-Jima, Bonin Islands, Japan. Rep. Fac. Sci. Shizuoka Univ., 10:145-155.

Leg 126 Shipboard Drilling Party, 1989. ODP Leg 126 drills the Izu-Bonin Arc. Geotimes, 34:36-38.

Lüthi, S. M., and Banavar, J. R., 1988. Application of borehole images to three-dimensional geometric modeling of eolian sandstone reservoirs, Permian Rotliegende, North Sea. AAPG Bull., 72:1074-1089.
Mandelbrot, B. B., 1983. The Fractal Geometry of Nature: New York (W. H. Freeman).

Matsuda, J., 1985. Sr isotopic studies of rocks from the Philippine Sea and some implications for the mantle material. In Shiki, T. (Ed.), Geology of the Northern Philippine Sea: Tokyo (Tokai Univ. Press), 63-78.

Middleton, G. V., 1965. The Tukey chi-squared test. J. Geol., 73:547-549.

Mogi, K., 1990. Seismicity before and after large shallow earthquakes around the Japanese islands. Tectonophysics, 175:1-34.

Moore, J. G., Clague, D. A., Holcomb, R. T., Lipman, P. W., Normark, W. R., and Torresan, M. E., 1989. Prodigious submarine landslides on the Hawaiian Ridge. J. Geophys. Res., 94:17465-17484.

Mutti, E., 1985. Turbidite systems and their relations to depositional sequences. In Zuffa, G. G. (Ed.), Provenance of Arenites: Dordrecht, The Netherlands (D. Reidel), 65-93

Mutti, E., and Ghibaudo, G., 1972. Un esempio di torbiditi di conoide sottomarina esterna: le Arenarie di San Salvatore (Formazione di Bobbio, Miocene) nell' Appennino di Piacenza. Mem. Acc. Sci. Torino Classe Sci. Fis. Nat., Ser. 4, No. 16

Parkash, B., and Middleton, G. V., 1970. Downcurrent textural changes in Ordovician turbidite greywackes. Sedimentology, 14:259-293.

Pezard, P., Lovell, M., and ODP Leg 126 Shipboard Scientific Party, 1990. Downhole images: electrical scanning reveals the nature of subsurface oceanic crust. Eos, 71:709.

Pickering, K. T., 1982. The shape of deep-water siliciclastic systems: a discussion. Geo-Mar. Lett., 2:41-46.

Pickering, K. T., Hiscott, R. N., and Hein, F. J., 1989. Deep Marine Environments: Clastic Sedimentation and Tectonics: London (Unwin Hyman).

Piper, D.J.W., Shor, A. N., and Hughes-Clarke, J. E., 1988. The 1929 "Grand Banks" earthquake, slump, and turbidity current. Spec. Pap.-Geol. Soc. Am., 229:77-92.

Plotnick, R. E., 1986. A fractal model for the distribution of stratigraphic hiatuses. J. Geol., 94:885-890.

Postma, G., 1976. Classification for sediment gravity-flow deposits based on flow conditions during sedimentation. Geology, 14:291-294.

Ricci Lucchi, F., 1975. Depositional cycles in two turbidite formations of the Northern Apennines, Italy. J. Sediment. Petrol., 45:3-43.

Ricci Lucchi, F., and Valmori, E., 1980. Basin-wide turbidites in a Miocene, over-supplied deep-sea plain: a geometrical analysis. Sedimentology, 27:241-270.

Shipboard Scientific Party, 1990. Explanatory Notes. In Taylor, B., Fujioka K., et al., Proc. ODP, Init. Repts., 126: College Station, TX (Ocean Drilling Program), 13-42.

Shultz, A. W., 1984. Subaerial debris-flow deposition in the Upper Paleozoic Cutter Formation. J. Sediment. Petrol., 54:759-772.

Smalley, R. F., Jr., Chatelain, J.-L., Turcotte, D. L., and Prévot, R., 1987. A fractal approach to the clustering of earthquakes: applications to the seismicity of the New Hebrides. Bull. Seismol. Soc. Am., 77:1368-1381.

Taylor, B., Fujioka, K., et al., 1990. Proc. ODP, Init. Repts., 126: College Station, TX (Ocean Drilling Program).

Taylor, B., Moore, G., Klaus, A., Systrom, M., Cooper, P., and MacKay, M., 1990. Multichannel seismic survey of the central Izu-Bonin Arc. In Taylor, B., Fujioka, K., et al., Proc. ODP, Init. Repts., 126: College Station, TX (Ocean Drilling Program), 51-60.

Tsunakawa, H., 1983. K-Ar dating on volcanic rocks in the Bonin Islands and its tectonic implication. Tectonophysics, 95:221-232.

Turcotte, D. L., 1989. Fractals in geology and geophysics. Pure Appl. Geophys., 131:171-196.

Waldron, J.WF., 1987. A statistical test for significance of thinning- and thickening-upward cycles in turbidites. Sediment. Geol., 54:137-146.

Walker, R. G., 1975. Generalized facies model for resedimented conglomerates of turbidite association. Geol. Soc. Am. Bull., 86:737-748.

Wallmann, P. C., Mahood, G. A., and Pollard, D. D., 1988. Mechanical models for correlation of ring-fracture eruption at Pantelleria, Strait of Sicily, with glacial sea-level drawdown. Bull. Volcanol., 50:327-339.

Yuasa, M., 1985. Sofugan Tectonic Line, a new tectonic boundary separating northern and southern parts of the Ogasawara (Bonin) Arc, northwest Pacific. In Nasu, N., Kobayashi, K., Uyeda, S., Kushiro, I., and Kagami, H. (Eds.), Formation of Active Ocean Margins: Tokyo (Terra Scientific), 483-496

Date of initial receipt: 11 December 1990

Date of acceptance: 29 May 1991

Ms 126B-118 